The enigmatic kinorhynch Cateria styx Gerlach, 1956 - A sticky son of a beach

Herranz, María; Di Domenico, Maikon; Sørensen, Martin V.; Leander, Brian S.

Published in:

Zoologischer Anzeiger

DOI:

10.1016/j.jcz.2019.05.016

Publication date:

2019

Document version

Publisher's PDF, also known as Version of record

Document license:

CC BY

Citation for published version (APA):

Herranz, M., Di Domenico, M., Sørensen, M. V., \& Leander, B. S. (2019). The enigmatic kinorhynch Cateria styx Gerlach, 1956 - A sticky son of a beach. Zoologischer Anzeiger, 282, 10-30.

https://doi.org/10.1016/j.jcz.2019.05.016 
Research paper

\title{
The enigmatic kinorhynch Cateria styx Gerlach, 1956 - A sticky son of a beach ${ }^{\text {in }}$
}

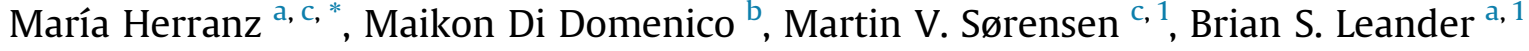 \\ ${ }^{a}$ Departments of Zoology and Botany, Biodiversity Research Centre, University of British Columbia, 2212 Main Mall, Vancouver, BC, V6T 1Z4, Canada \\ b Centro de Estudos do Mar, Universidade Federal do Paraná, Pontal do Paraná, Brazil

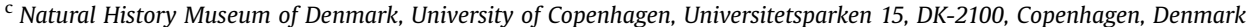

\section{A R T I C L E I N F O}

\section{Article history:}

Received 21 February 2019

Received in revised form

16 April 2019

Accepted 24 May 2019

Available online 6 June 2019

\section{Keywords:}

Kinorhyncha

Morphology

Adhesion

Friction

Hydrophobicity

Dorsal organ

\begin{abstract}
A B S T R A C T
Since its discovery in the mid-1950'ies, Cateria has been an enigmatic kinorhynch genus due to its aberrant worm-like shape and extremely thin cuticle. However, the rare occurrence of the species, only found in sandy intertidal habitats, and the poor preservation of the type material have hampered detailed studies of the genus over time. Now, sixty years after the original description of Cateria styx, we present an extensive morphological and functional study based on new material collected from its type locality in Macaé, Brazil. We combine live observations with detailed scanning electron microscopy data, new light microscopy material, confocal laser scanning microscopy and three-dimensional rendering. These observations show that $C$. styx displays a complex array of cuticular structures (spines, spinoscalids and extraordinarily complex cuticular ornamentation) that we interpret to be adaptations for mechanical adhesion, through friction and interlocking, in an interstitial habitat; the enigmatic dorsal organ, is a hydrostatic structure which function is inferred to be adhesive. Additional morphological traits in C. styx include: extremely elongated primary spinoscalids that cannot be completely retracted in the trunk; a reduced number of spinoscalids; sixteen elongated hairy patches in the introvert; fifteen trichoscalids that vary in length; the absence of a neck; dorsal spines being alternatingly displaced to either left or right side paradorsal positions; and high intraspecific variation in the number and position of glandular openings in the trunk.
\end{abstract}

() 2019 Elsevier GmbH. All rights reserved.

\section{Introduction}

Beaches are dynamic coastal ecosystems that harbour a complex array of macroscopic and microscopic organisms. Most of the microscopic forms are animals and protists ranging between 30 and $500 \mu \mathrm{m}$ that reside in the interstices of the sediment, collectively referred to as meiofauna or meiobenthos (Giere 2009). This sandy habitat is structured by the interactions between sediment, waves and tides (McLachlan \& Defeo 2017). Meiofaunal communities represent 24 of 35 animal phyla and are often species rich and abundant, sometimes exceeding the total biomass of the

\footnotetext{
4 This article is a part of the Fifth International Scalidophora Workshop special issue published in Zoologischer Anzeiger 282C, 2019.

* Corresponding author. Departments of Zoology and Botany, Biodiversity Research Centre, University of British Columbia, 2212 Main Mall, Vancouver, BC, V6T 1Z4, Canada.

E-mail addresses: maria.herranz@botany.ubc.ca, mariaherranzm@gmail.com (M. Herranz).

${ }^{1}$ Shared last authorship.
}

macrofauna living in the same geographical area (McLachlan \& Defeo 2017; Giere 2009).

Kinorhyncha is an exclusively meiobenthic group of marine, free-living metazoans that inhabit sediments from intertidal to abyssal depths, extending from polar to tropical latitudes (Neuhaus 2013; Sørensen \& Pardos 2008). Currently, there are around 275 described kinorhynch species accommodated in 30 different genera. Among these genera, Cateria is one of the most enigmatic due to its aberrant worm-like shape, extremely thin cuticle and contentious phylogenetic position (Dal Zotto et al. 2013; Sørensen et al. 2015). Cateria currently includes two species: Cateria gerlachi Higgins, 1968 and Cateria styx Gerlach, 1956. C. gerlachi was described from Waltair, India (Higgins 1968), initially misidentified as C. styx by Rao \& Ganapati (1966), and more recently redescribed based on material from the type locality and Sri Lanka (Neuhaus \& Kegel 2015). C. styx, was described from Macaé, Brazil (Gerlach 1956), subsequently recollected at Cavaleiro Beach, Macaé (Higgins 1968), and also reported from Ubatuba, Brazil (Higgins 1968) and Valparaiso, Chile (Brown \& Higgins 1983). Previously 
unpublished findings include specimens collected by Dr. Tatiana F. Maria at Praia de Guaxindiba, São Francisco, Brazil. Additionally, C. styx was reported in Angola (Delamare Deboutteville 1957); however, the species identification is considered doubtful (Neuhaus \& Kegel 2015). All the localities from which Cateria was collected are sandy beaches, and most of the specimens were found intertidally $10-60 \mathrm{~cm}$ below the sediment surface (Brown \& Higgins 1983; Gerlach 1956; Higgins 1968; Higgins \& Rao 1979; Rao \& Ganapati 1966) or at the surface in case of $C$. gerlachi from Sri Lanka (Neuhaus \& Kegel 2015). Even though specimens of Cateria have been collected at multiple occasions over time, very few specimens have been used for detailed studies.

Recently, a study by Neuhaus \& Kegel (2015) redescribed C. styx and $C$. gerlachi based on detailed light microscopy observations of all available type and non-type material, combined with scanning electron microscopy observations of freshly sampled specimens of C. gerlachi collected from Sri Lanka. However, the new information provided for $C$. styx was limited because of the lack of new material and the poor condition of the available specimens (Neuhaus \& Kegel 2015).

Live observations and video documentation in kinorhynch studies are quite rare. This is not different for Cateria for which the only live observations available are restricted to those form Rao \& Ganapati (1966), who described C. gerlachi (initially identified as C. styx) as "highly thigmotactic", meaning sensitive to disturbance and very sticky, adhering firmly to the substrate with the aid of the scalids and the trunk spines (Rao \& Ganapati 1966). No other subsequent study includes live observations in neither of the two Cateria species.

Multiple aspects of Cateria morphology and biology are still poorly explored, yet being one of the most enigmatic kinorhynch genera (showing an elongated narrow trunk with a thin cuticle, a modified neck and introvert, complex cuticular ornamentation and the presence of a bizarre dorsal organ in C. styx). This paper focuses on the morphology of $C$. styx, based on fresh material collected at the type locality in Macaé, Brazil and combining scanning electron microscopy, confocal laser scanning microscopy, light microscopy and live animal observations. We provide for the first time a detailed description of $C$. styx based on SEM data and describe the dynamics and putative function of its dorsal organ, based on internal and external detailed morphology, live images and video analyses. In addition, we study the extraordinary ornamentation of C. styx's cuticle and its implications for hydrophobicity and adhesion.

\section{Materials and methods}

\subsection{Sampling and sample processing}

Specimens of C. styx were collected on March 10, 2015 at Cavaleiro Beach by the end of the street Rua Bariloche in Macaé, Brazil (Position: $22^{\circ} 21.985^{\prime} \mathrm{S} 041^{\circ} 46.453^{\prime} \mathrm{W}$ ). The beach is the assumed type locality for C. styx (Gerlach (1956) only says 'beach in Macaé'), and the same locality that was sampled for the study of Higgins (1968). Sediment samples were taken from 50 to $70 \mathrm{~cm}$ deep holes that were dug on the beach, 3 and $6 \mathrm{~m}$ below the high tide mark, from sand at the water line, and subtidal sand at ca. $50 \mathrm{~cm}$ water depth. The sand collected $3 \mathrm{~m}$ from the high tide mark yielded very high numbers of specimens $(>200)$, whereas a moderate number (ca. 20) was found $6 \mathrm{~m}$ below the high tide mark. No specimens were found subtidally or in sediment from the water line. All specimens used in the present study originate from the sample taken $3 \mathrm{~m}$ below the high tide mark (sample no. MVS-0180BRA-25).
The extraordinary clean sand was placed in buckets, mixed with seawater and stirred vigorously. The coarse sand settled quickly, and the overlying water with kinorhynchs suspended or trapped on the surface, was poured through a net with a $60 \mu \mathrm{m}$ mesh. The concentrated meiofauna samples from the net were brought directly to the laboratory at the Federal University of Macaé and sorted while the specimens were still alive.

\subsection{Live observations}

Live specimens were placed between a glass slide and a cover glass, and observed with a Nikon Eclipse E200 stereomicroscope and a Leica M205 confocal microscope. Video recordings of the live specimens were made with the software Leica Application Suite v.4.1.0 in the confocal microscope.

\subsection{Preparation for light- and scanning electron microscopy}

Specimens for light microscopy (LM) and scanning electron microscopy (SEM) were picked up and placed for a few seconds in a drop of distilled water to make the specimens stretch, or at least prevent them from coiling up during fixation. The stretched specimens were subsequently transferred to tubes with either $4 \%$ formalin (for LM) or trialdehyde (for SEM) and stored for preparation.

Specimens for LM were dehydrated through a graded series of water/glycerin, and stored overnight in $100 \%$ glycerin. Each specimen was then placed in a drop of Fluoromount $G$, mounted between two cover glasses, and attached to an $\mathrm{H}-\mathrm{S}$ plastic slide. The specimens are stored in the Natural History Museum of Denmark (NHMD) under catalogue numbers NHMD-267150 to 267163.

Specimens for SEM were split into two groups, and some were prepared and examined by either $\mathrm{MH}$ at University of British Columbia (UBC) or MVS at NHMD. Specimens examined at NHMD were dehydrated through a water-ethanol series, and subsequently transferred to acetone through an ethanol-acetone series, critical point dried, mounted on aluminium stubs, sputter coated with a mix of platinum-palladium and examined in a JEOL JSM-6335F Field Emission SEM. Specimens examined at UBC were dehydrated through a graded series of water-ethanol and critical point dried. The dried specimens were mounted on aluminium stubs, sputter coated with a mix of gold-palladium and examined under a Hitachi S4700 Field Emission SEM at the Bioimaging Facility at UBC.

\subsection{Preparation for immunohistochemistry and confocal laser scanning microscopy}

A total of 25 specimens were isolated and fixed for immunohistochemistry (IHC) and confocal laser scanning microscopy (CLSM). Live specimens were isolated, relaxed with a $\mathrm{MgCl}_{2}$ solution for 5-10 min and fixed in 4\% paraformaldehyde in seawater for $1 \mathrm{~h}$ at $4{ }^{\circ} \mathrm{C}$, subsequently washed multiple times in phosphate buffered saline (PBS) and stored in PBS with $0.05 \%$ of sodium azide $\left(\mathrm{NaN}_{3}\right)$ to avoid microbial growth.

A subset of the fixed specimens (ca.15) was labelled with phalloidin (Alexa Fluor 633, Invitrogen) at a concentration of $1: 100$ in order to study the musculature, combined with hoechst (Sigma Aldrich) to label and detect DNA. Remaining specimens (ca. 10) were prepared for IHC. Prior to any IHC treatment the cuticle of every specimen was cut in order to facilitate the penetration of the reagents. Dissected specimens were incubated in PBT (PBS $+0.5 \%$ Triton X-100) for 30 min followed by incubation in blocking solution (PBT $+0.5 \%$ bovine serum albumin $+10 \%$ normal goat serum) at $4{ }^{\circ} \mathrm{C}$ overnight. In order to visualize the nervous system architecture, the specimens were treated with 
mouse anti-acetylated alpha-tubulin (Sigma-Aldrich) as a primary antibody in a concentration of $(1: 400)$ in blocking solution for $72 \mathrm{~h}$ at $4{ }^{\circ} \mathrm{C}$. The primary antibody was then removed with multiple washes of PBT. Posteriorly, the specimens were incubated with Alexa Fluor 647 anti-mouse (Invitrogen) secondary antibody at a concentration of $1: 400$ in blocking solution at $48{ }^{\circ} \mathrm{C}$ for $72 \mathrm{~h}$. The secondary antibody was washed out with multiple PBT exchanges prior to mounting.

For CLSM imaging, stained specimens were transferred through a graded glycerol-PBS series (from 10, 20, 40, 60\% glycerol) and mounted in $60 \%$ glycerol $+1 \mathrm{X}$ PBS solution on glass slides with a coverslip elevated with modelling clay. Specimens were analysed and imaged with an Olympus FV1000 Multiphoton CLSM at the UBC Bioimaging facility. Optical sections and z-stack projection micrographs were compiled with Fiji, version 2.00 (Wayne Rasband, National Institutes of Health). Three-dimensional reconstructions and volume renderings were performed with AMIRA 5.0 (FEI Visualization Sciences Group, Mérignac Cédex, France). Original CLSM micrographs were edited with Adobe Photoshop CS6 (Adobe Systems Incorporated, San Jose, CA). Schematics and figure plates were prepared with Adobe Illustrator CS6 (Adobe Systems Incorporated, San Jose, CA).

\section{Results}

\subsection{Live observations}

After extraction and isolation, live specimens of C. styx were observed and filmed. At first sight, it was noticeable that C. styx moved in an unusual manner that diverged from the typical kinorhynch-like motion observed in other genera. Most kinorhynchs move by continuously everting and withdrawing their head while directing the movement using the musculature associated with the first trunk segments. Instead, C. styx shows a characteristic accordion-like movement where the trunk seems to stretch and contract along its anterior-posterior axis (Supplementary file 1). This, together with the introvert motion, might contribute to facilitate forward movement through the sediment. The accordion-like movements are combined with fast twisting and coiling of the trunk giving the appearance of a worm rather than a kinorhynch. The introvert of $C$. styx shows extremely long primary spinoscalids that never get completely retracted in the trunk. When partly retracted, they form a funnel shape that, at first glance, can resemble the tentacles of filter feeding polychaetes.

Supplementary video related to this article can be found at https://doi.org/10.1016/j.jcz.2019.05.016.

Another singularity of $C$. styx is the presence of a dorsal organ located in between trunk segments 5-6. Freshly extracted specimens did not show any external trace of the organ. However, after a couple of hours once the animals started to get stressed (due to the increase of water temperature, salinity or simply by manipulation), most of the specimens started everting their dorsal organs. The full eversion of the organ takes one to two minutes (Supplementary file 2 ). Initially the specimen slows down, staying still and simultaneously but slowly extending the introvert and elongating the trunk segments (Fig. 1A and Supplementary file 2). Posteriorly, due to an increase of the internal pressure of the trunk, a small protuberance starts appearing in between segment 5 and 6 (Fig. 1B). This protuberance enlarges and the dorsal organ progressively emerges until it reaches a critical threshold at which point the process speeds up greatly, and in less than a second, the dorsal organ unfolds completely (Fig. 1C-E). Once the dorsal organ is extended, it grows for additional 2-3 s until it reaches its full size (ca. $120 \mu \mathrm{m}$ in length) (Fig. 1F, G). Specimens with the dorsal organ everted remained alive but quite inactive (Supplementary file 2).
Supplementary video related to this article can be found at https://doi.org/10.1016/j.jcz.2019.05.016.

It is important to stress that all our live observations were from specimens isolated from their natural environment under laboratory conditions (e.g., in the absence of sediment, increase of light, temperature, etc.), which might have affected their behaviour.

\subsection{Introvert}

The head consists of an introvert and an extraordinary long mouth cone (Figs. 2A-D, 3A, 4). When the head is fully retracted into the trunk, the muscular pharynx of the mouth cone can often be observed inside segments 4 and 5 , or even reaching segment 6 . Unlike many other kinorhynchs that often are fixed with both introvert and mouth cone fully everted, most examined C. styx specimens would have the introvert everted, whereas the mouth cone would still be retracted (Fig. 2A). In such specimens, the pharynx could be observed inside segments 4 and 5, while the outer oral styles would be in segments 2 and 3 (Fig. 2D). Only a single specimen, mounted for LM, had both introvert and mouth cone everted. Among the remaining specimens, mounted for LM as well as SEM, several had only the introvert everted. Hence, data on outer oral styles is available from LM only, whereas no data is available for inner oral styles.

C. styx has nine long and slender outer oral styles (54 $\mu \mathrm{m}$ in length), composed of three joined units (Fig. 2D). The outer oral styles attach anterior to, and medially in, each introvert section, except the middorsal section 6 that has no style (Fig. 4). The outer oral styles are arranged around a terminal mouth opening surrounded by a conspicuous ring. We interpret this ring as a pharyngeal crown, but confirmation with SEM would be desirable (Fig. 2C).

The introvert consists of four distal rings of spinoscalids and one proximal ring of trichoscalids, separated by elongated areas with dense hair covering (Figs. 3 and 4). Ring 01 has ten primary spinoscalids (Fig. 4). The primary spinoscalids varies in length, but are generally very long (up to $117 \mu \mathrm{m}$ ), slender and flexible (Figs. 2A, B, $E$ and $3 A, E$ ). Each scalid consists of a short basis that attaches to the slender end-piece in a knee-like joint. The scalid bases are smooth and without any conspicuous cuticular structures, whereas the end-pieces are laterally flattened with all sides covered with numerous minute hairs (Fig. 3E). Internal septa are not present (Fig. 2E). A pair of spinose processes, that superficially resembles outer oral styles, attaches anterior to the base of each primary spinoscalid (Figs. 2A, 3A, B and 4). Each process ( $48 \mu \mathrm{m}$ in length) is formed by a spinous lamella with a medial, longitudinal fold, giving it a V-shaped appearance in cross-section. Each pair of lamellae appears to be partially fused.

Ring 02 has ten spinoscalids that attach medially in each introvert sector (Fig. 4). The spinoscalids ( $54 \mu \mathrm{m}$ in length) in this ring are thinner than any other spinoscalids in the introvert, and appear much more rigid, even though they tend to curve near their distal ends (Fig. 3A). They appear smooth, except for a row of fringelike hairs on the inferior surfaces (Fig. 3F). Ring 03 has twenty spinoscalids, arranged pairwise in each sector, and Ring 04 has five spinoscalids, present medially and in odd-numbered sectors only (Fig. 4). The spinoscalids in these two rings resemble each other. They are about $34 \mu \mathrm{m}$ in length, and consist of a short base with a knee-like joint that connects with the laterally flattened and rather flexible end-piece (Fig. 3C, E). Most proximally the end-pieces have densely set minute hairs on their lateral sides, but only a short distance from the basal joint, the hairs will change to much more well-organized rows of plate-like scales. The scales in each row are slightly overlapping, like clay tiles on a roof top, and the end-piece has three rows in total: a broad row on each of the lateral sides of 

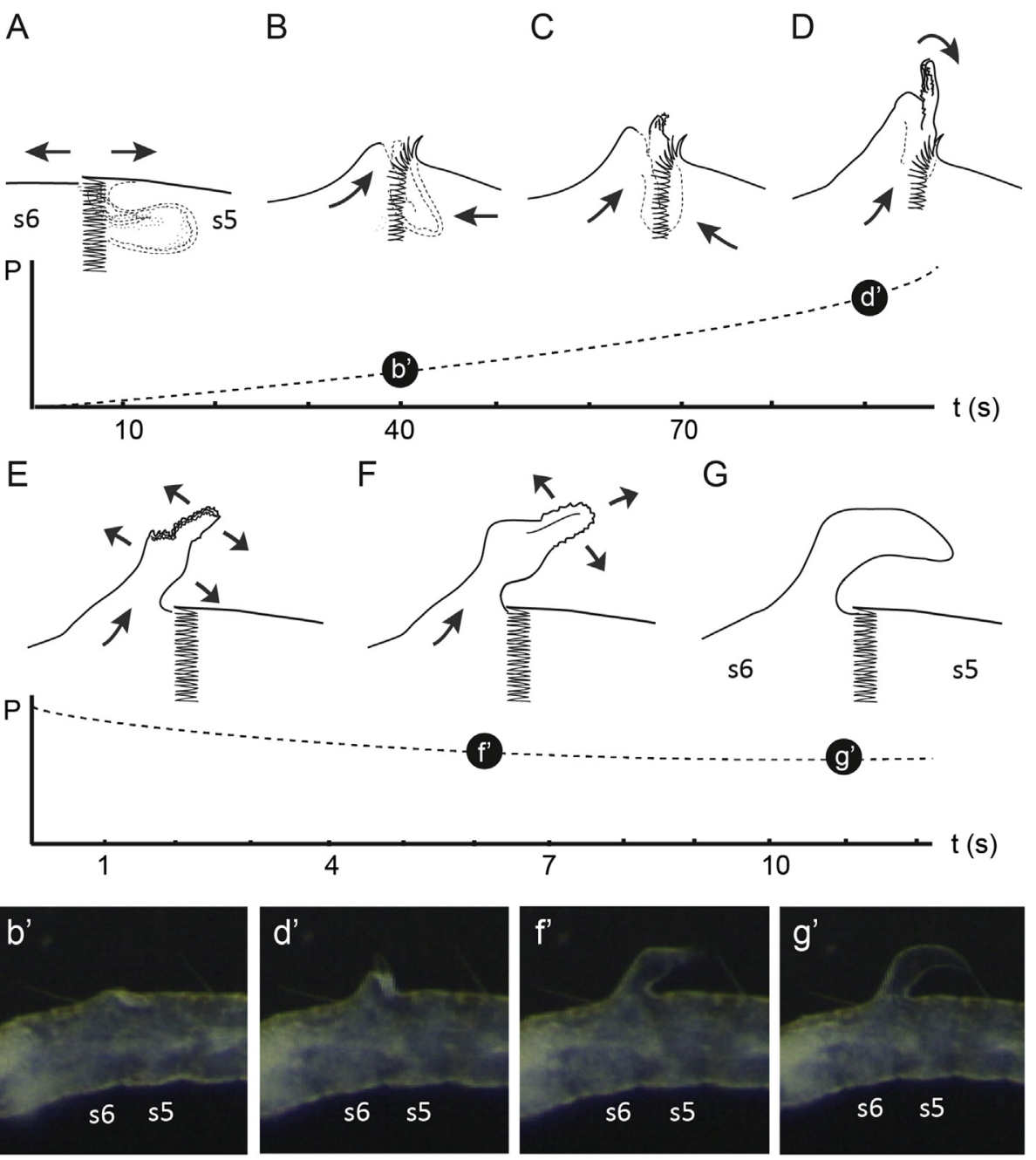

Fig. 1. Dorsal organ eversion. A-G. Diagrams of the different stages during eversion of the dorsal organ, from completely retracted (A) to completely extended (G). b', d', f', $\mathbf{g}$ '. Snapshots from a live specimen of Cateria styx (see Supplementary file 2) corresponding with diagrams B, D, F, G respectively. Arrows in the line art indicate the direction of the movement. Graphs under the diagrams indicate the estimated relative pressure along time. Abbreviations: P, pressure; s, seconds; s5/6, segments 5/6; t, time.

the end-piece, and a narrower row that wraps around the exterior surface of the end-piece (Fig. 3G).

Described sector-wise, the spinoscalids form a diamond in oddnumbered sectors, and a chevron in even-numbered sectors (Fig. 4).

No further spinoscalids are present posterior to Ring 04. Instead, the introvert carries elongate patches with densely set hairs (Figs. 3A, C, D, H and 4). The more lateral introvert sectors have two hair patches, whereas only a single patch is present in sectors $1,2,6$, and 10 (Fig. 4).

A total of fifteen trichoscalids are present posteriorly on the introvert (Fig. 4). The trichoscalids are dimorphic and appear either in a thin and shorter $(15 \mu \mathrm{m})$, or a stout and longer $(30 \mu \mathrm{m})$ version (Figs. 2F and 3A, D, H). Short trichoscalids appear as pairs in sectors 3 and 9 , as a single median structure in sector 6 , and paired up with a long trichoscalid in sectors 5 and 7 (Fig. 4). Long trichoscalids appear as pairs in sectors 4 and 8 , as single median structures in sectors 2 and 10, and paired up with a short trichoscalid in sectors 5 and 7 (Fig. 4). All trichoscalids attach in the posterior margin of the haired patches (Figs. 3A, C, D, H and 4).

The most posterior part of the introvert is sculptured, but consists otherwise of completely undifferentiated cuticle (Fig. $3 \mathrm{H}$ ). There is no differentiated neck region or cuticular closing apparatus at the head opening, hence, no indications of structures that can be considered homologous with placids as found in most other kinorhynchs. However, at least three circular muscles are present inside the introvert, at the level of the hairy patches, suggesting that they play a role in the partial closing of the head opening. It is unclear to what extent $C$. styx is able to withdraw its head and close the head opening. Several examined specimens mounted for SEM and LM showed a complete retraction of the mouth cone, and a partial retraction of the introvert where most of the spinoscalids still would be sticking out of the head opening (Fig. 2B). The strongest retractions were observed in a few specimens where the anterior $1 / 4$ of segment 1 also would fold inwards and at least partially close the head opening. But even in these specimens, end-pieces of spinoscalids would still be sticking out through the opening. Live observations showed specimens that would make a complete withdrawal of the introvert, but still have their spinoscalids exposed (Supplementary file 1 ).

\subsection{Trunk and cuticular structures}

The following description of cuticular trunk structures is done with emphasis on the general cuticular ornamentation, and position of spines, tubes, glandular cell outlets and sensory spots. The 

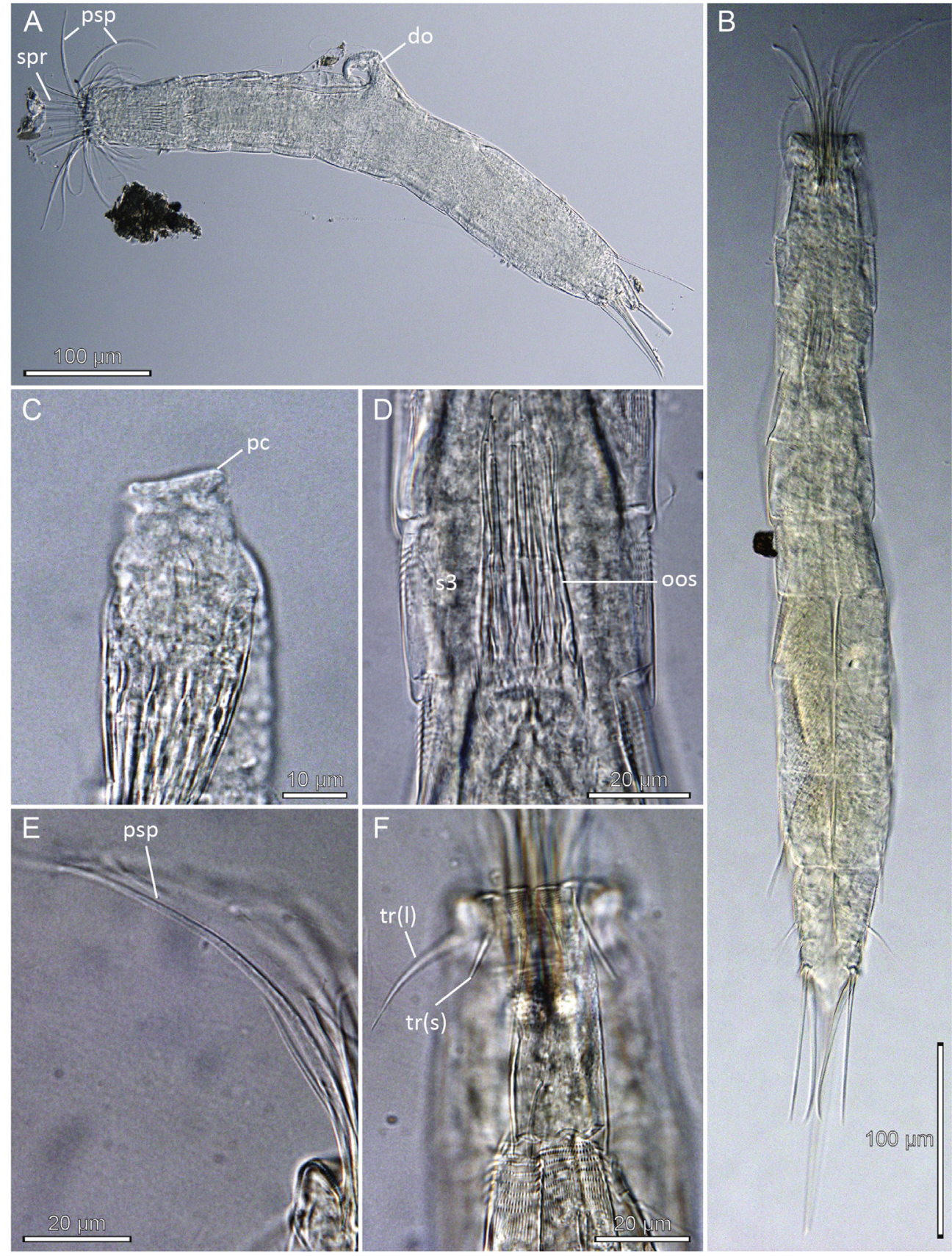

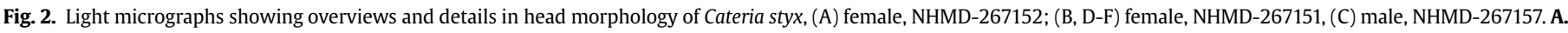

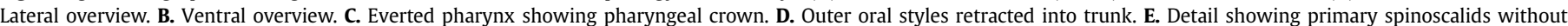

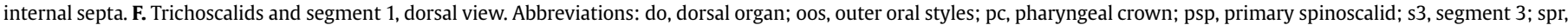
spinose processes; $\operatorname{tr}(1 / \mathrm{s})$, trichoscalid (long/short).

terminology for sensory spots follows Neuhaus \& Kegel (2015), but some positions along the longitudinal axes are interpreted slightly different.

Each trunk segment is composed of either a single, wrapped tergal plate with midventral articulation, or a tergal and a sternal plate. Plate junctions are visible internally as well as on the cuticular surface. Segment 1 is partially differentiated into single tergal and sternal plates by incomplete tergosternal junctions that are only present on the posterior segment half (Figs. 5B and 6A). Segments 2 to 6 are fully differentiated into single tergal and sternal plates, but the sternal plates get gradually narrower on the more posterior segments, and on segment 6 it is mostly a narrow, midventral wedge (Fig. 5D). Each segment from segment 7 to 11 consists only of a tergal plate that wraps around the trunk and meets itself in a midventral articulation.

\subsubsection{Cuticular ornamentation}

The cuticular ornamentation in C. styx is extremely diverse from segment to segment, and even within the same segment, showing several structures and patterns that appear to be unique for the genus, and in certain cases, even for the species.

The ornamentation of segment 1 can be divided into three different kinds that appear along three transverse zones on the segment. The three kinds of ornamentation are best described as: 


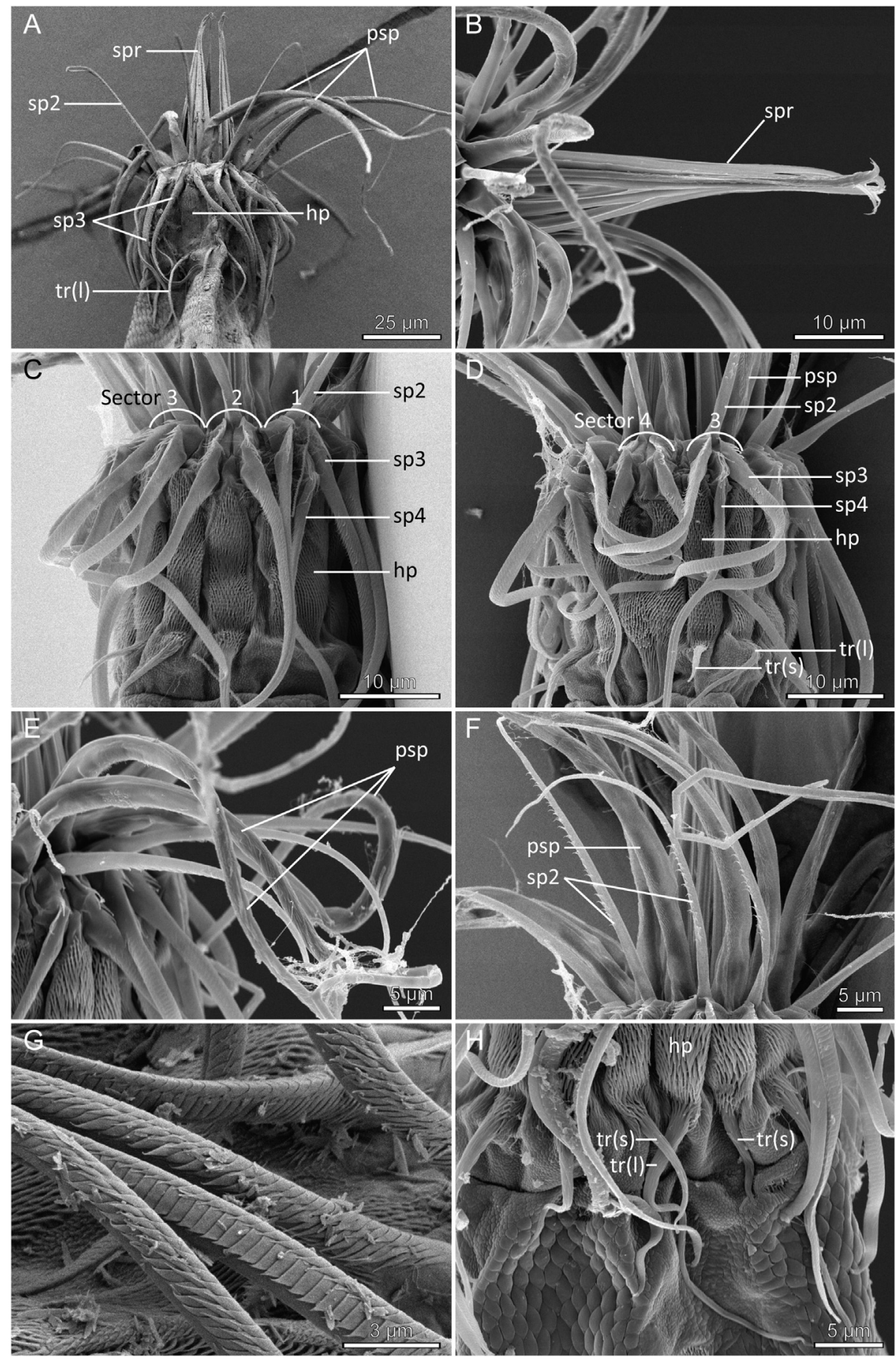

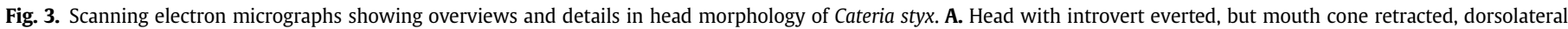

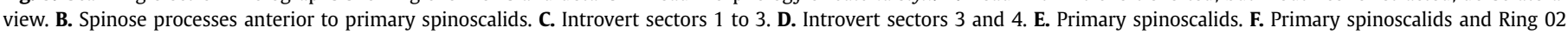

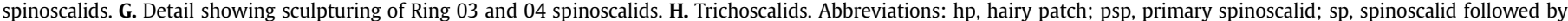
introvert ring number; spr, spinose processes; $\operatorname{tr}(\mathrm{l} / \mathrm{s})$, trichoscalid (long/short).

dragon scale-like ornamentation covering the anterior half of the segment, broad palisade-like ornamentation present in a short zone medially on the segment, and narrow palisade-like ornamentation present in the posterior $1 / 3$ of the segment (Figs. $5 \mathrm{~A}, \mathrm{~B}$ and $6 \mathrm{~A}-\mathrm{C}$ ). The dragon scale-like ornamentation is composed of hexagons arranged in transverse rows (Fig. 6A-C). The position of the hexagons is shifted laterally, half a hexagon-width, so that the tip of each hexagon fits in between the tips of the hexagons in the anterior row (Fig. 6A). There are about nine to thirteen transverse rows of hexagons. The hexagons in the anteriormost rows are nearly as wide as long, but they gradually become longer in the more posterior rows, which also make the pattern appear more well-organized (Fig. 6A-C). The zone with the dragon scale-like ornamentation is interrupted by seven longitudinal areas with same irregular knobby surface as the cuticle in the posterior part of the introvert. The areas extend from the anterior segment margin and down to the second most posterior row of hexagons, where they all end by the cuticular marking of a muscle attachment site 


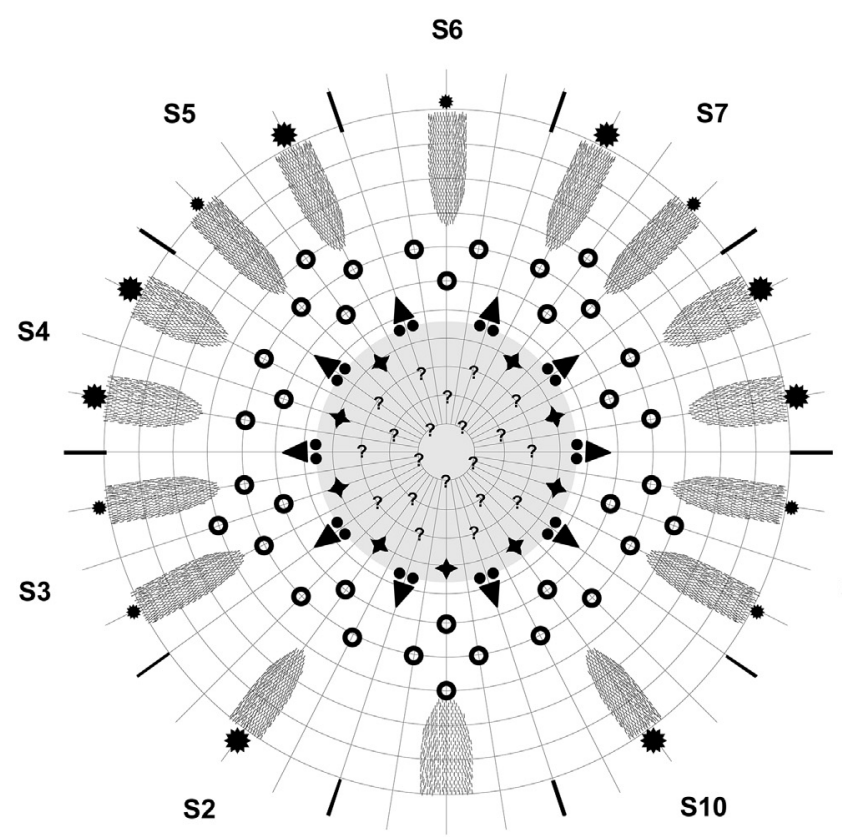

S8

S1

Scalid and style arrangement

\begin{tabular}{|c|c|c|c|c|c|c|c|c|c|c|c|}
\hline Ring/Section & 1 & 2 & 3 & 4 & 5 & 6 & 7 & 8 & 9 & 10 & Total \\
\hline 00 outer oral styles $\leftarrow$ & 1 & 1 & 1 & 1 & 1 & 0 & $\overline{1}$ & 1 & 1 & 1 & 9 \\
\hline 01 spinose processes $\bullet \bullet$ & 2 & 2 & 2 & 2 & 2 & 2 & 2 & 2 & 2 & 2 & 20 \\
\hline 01 primary spinoscalids $\nabla$ & 1 & & & & & & & & & & 10 \\
\hline 02 spinoscalids & 1 & 1 & 1 & 1 & 1 & 1 & 1 & 1 & 1 & 1 & 10 \\
\hline 03 spinoscalids & 2 & 2 & 2 & 2 & 2 & 2 & 2 & 2 & 2 & 2 & 20 \\
\hline 04 spinoscalids & 1 & 0 & 1 & 0 & 1 & 0 & 1 & 0 & 1 & 0 & 5 \\
\hline 05 spinoscalids & 0 & 0 & 0 & 0 & 0 & 0 & 0 & 0 & 0 & 0 & 0 \\
\hline 06 spinoscalids & 0 & 0 & 0 & 0 & 0 & 0 & 0 & 0 & 0 & 0 & 0 \\
\hline 07 spinoscalids & 0 & 0 & 0 & 0 & 0 & 0 & 0 & 0 & 0 & 0 & 0 \\
\hline Total scalids & 4 & 3 & 4 & 3 & 4 & 3 & 4 & 3 & 4 & 3 & 35 \\
\hline 08 trichoscalids & 0 & 1 & 2 & 2 & 2 & 1 & 2 & 2 & 2 & 1 & 15 \\
\hline
\end{tabular}

Fig. 4. Diagram of mouth cone (grey area), introvert and placids in Cateria styx, showing distribution of outer oral styles, spinoscalids and trichoscalids. The table below shows the scalid arrangement by sector (S1 to S10), and summarized scalid numbers by rings and sectors. Question marks indicate that the occurrences of eventual inner oral styles are uncertain.

(Fig. 6A-C). They are present as one, unpaired middorsal area, and paired laterodorsal, midlateral and ventrolateral areas (Fig. 6A-C). The middorsal area ends at one middorsal and a pair of paradorsal muscle attachment sites (Fig. 6C). The laterodorsal area ends at a rounded muscle attachment site. The midlateral area also ends at a rounded muscle attachment site, but this site is immediately followed by a second, more elongate muscle attachment site, that overlaps the zone with broad palisade-like ornamentation (Fig. 6B). The ventrolateral areas are slightly broader than the midlateral ones, and continue to the posterior segment margin. They also mark the borders between the tergal and the midsternal plates. Within these areas a pair of oval lateroventral muscle attachment sites is present, anterior to a pair of more elongate ventrolateral attachment sites (Fig. 6A).

The zone with broad palisade-like ornamentation is composed of a single transverse row of elongate pointed rods. It is only interrupted by the posteriormost pair of midlateral muscle attachment sites, and at the tergosternal junctions (Fig. 6A). This zone is followed by the posteriormost zone with narrow palisadelike ornamentation (Fig. $6 \mathrm{~A}-\mathrm{C}$ ). This ornamentation resembles the broad palisade-like, but the rods are much longer and also narrower.

The ornamentation of segment 2 can also be divided into three transverse zones, but the anteriormost zones differ on the tergal and sternal plates. On the tergal plate, the ornamentation of the anteriormost zone is formed by up to seven transverse bands of fringes (Figs. 5A and 6B, C). Each fringe tip is formed by a pointed, bifurcated hair with a median cleft (Fig. 6B). The anteriormost zone of the midsternal plate has dragon scale-like ornamentation (Fig. 6A). The median and posteriormost zones are composed of broad-, followed by narrow palisade-like ornamentation, as on segment 1 (Fig. 6A-C). The median zone with broad palisade-like ornamentation narrows in the sublateral positions, disappears completely around the lateral accessory positions, but reappears again on the midsternal plate (Fig. 6A, B).

Segments 3 to 9 have identical ornamentation, with transverse fringes forming a zone on the anteriormost $1 / 3$ of the segment, and now expanding around the entire segment, inclusive the ventral side (Figs. 5A-F, 6B-D, 7 and $8 \mathrm{~A}-\mathrm{C}$ ). Median and posteriormost zones are composed of broad- and then narrow palisade-like ornamentation, as on segment 2 (Figs. 5A-F, 6B-D, 7 and $8 \mathrm{~A}-\mathrm{C}$ ).

On segment 10 the ornamentation is only divided into two zones. The anteriormost covers about $2 / 3$ of the segment, and consists mainly of long, fringe-like hairs (Fig. 8A, D, E). The hairs are still arranged in transverse rows, but more disorganized than on the preceding segments. The posteriormost part also has hairs, but these are way shorter, and not arranged in rows (Fig. 8A, D, E). The tergal plate of segment 11 is covered with long hairs on the anterior half, whereas the posterior half, and the ventral side, have a dense covering of short hairs (Fig. 8A, F, G).

\subsubsection{Distribution of cuticular structures}

The presence and location of cuticular structures, inclusive spines, tubes, sensory spots, and glandular cell outlets are summarized in Table 1. It confirms to great extent the observations of Neuhaus \& Kegel (2015), but includes also several amendments.

Segment 1 with large sensory spots type 1 in middorsal and laterodorsal positions; the sensory spots are rounded to oval with a central or slightly more anterior pore with an emerging sensory cilium (same morphology for all sensory spots type 1 on segments 2 to 10 ) (Fig. 6B, C). Additional sensory spots type 5 (sensu Neuhaus \& Kegel, 2015) are present anterior to segment 1, on the most basal part of the introvert, in subdorsal and sublateral positions; sensory spots type 5 are generally very hard to visualize with SEM (Figs. $3 \mathrm{H}$ and 6B), whereas they appear more distinct in LM. Glandular cell outlets are present medially on the segment, in the zone with broad palisade-like ornamentation, in paradorsal, laterodorsal, sublateral and lateroventral positions (Fig. 6B, Table 1); the presence of these glandular cell outlets shows great individual variation, and one or more outlets were missing in some of the examined specimens, independent of gender or symmetry. Muscular attachment sites are present in middorsal, paradorsal, laterodorsal, midlateral and ventromedial (two pairs) positions (Fig. 6A-C). One additional, more elongate pair of muscular attachment sites is present in midlateral positions.

Segment 2 with dorsal acicular spine which is slightly displaced, either left or right towards paradorsal position. Sensory spots type 1 present in paradorsal, laterodorsal, and ventromedial positions (Figs 5A, B and 6A-C, Table 1). The paradorsal sensory spot is unpaired, and appears consistently to the right side; one specimen had one additional ventromedial sensory spot in its right side, located anterior to and partly fused with its other ventromedial sensory spot. Sensory spots type 5 present middorsally, on anterior part of segment. Glandular cell outlets present in laterodorsal and sublateral positions; presence of outlets differs between individuals (Table 1). Muscle attachment sites present on pachycyclus in subdorsal and ventrolateral positions, and medially on segment in midlateral positions; midlateral attachment sites are large and elongated (Fig. 6B). 

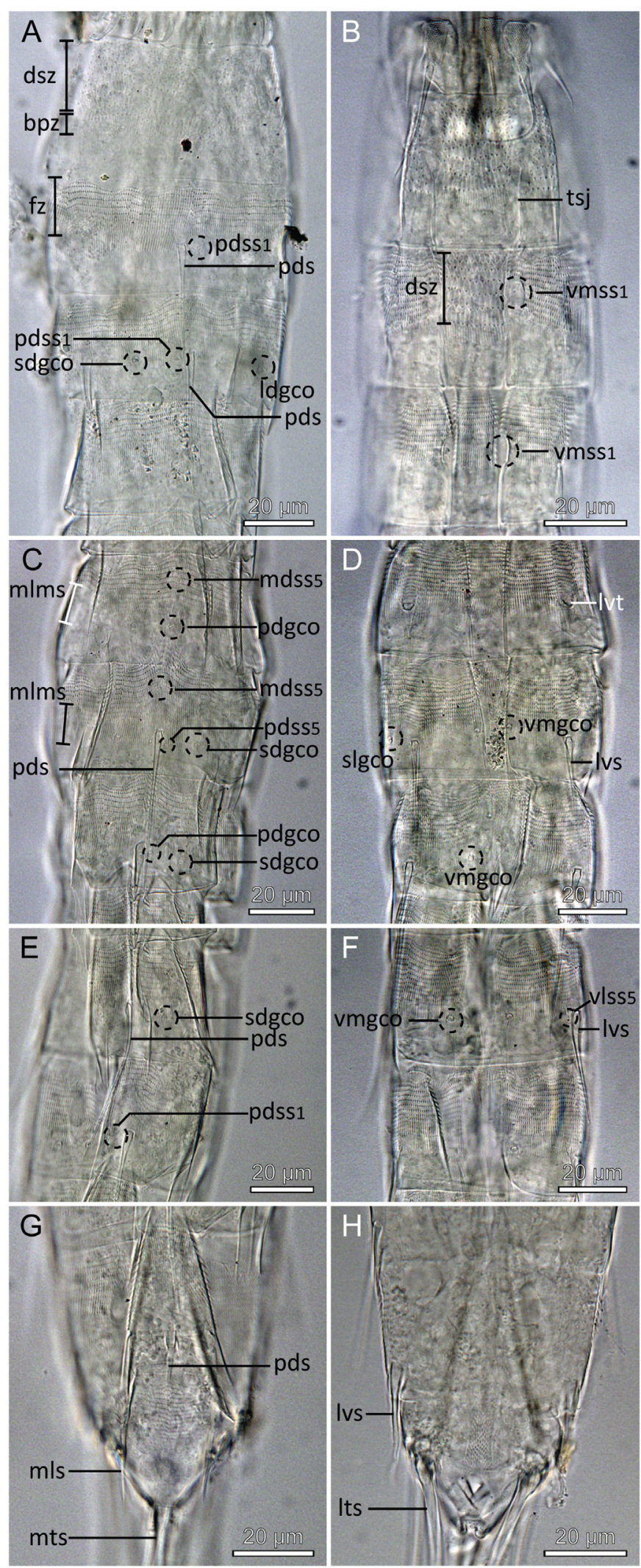

Fig. 5. Light micrographs showing trunk morphology in male specimen of Cateria styx, NHMD-267150. A. Segments 1 to 4, dorsal view. B. Segments 1 to 3, ventral view. C. Segments 5 to 7, dorsal view, and D. Ventral view. E. Segments 8 to 9, dorsal view, and F. Ventral view. G. Segments 10 to 11 , dorsal view, and $\mathbf{H}$. Ventral view. Abbreviations: bpz, broad palisade-like ornamentation zone; dsz, dragon scale-like ornamentation zone; fz, fringed ornamentation zone; ldgco, laterodorsal glandular cell outlet; lts,
Segment 3 with dorsal acicular spine being slightly displaced towards paradorsal position, to opposite side of the paradorsal spine on preceding segment. Sensory spots type 1 present in paradorsal and ventromedial positions (Fig. 6C, D); the paradorsal sensory spot is unpaired, and appears consistently to the left side (Fig. 6C). Sensory spots type 5 present in middorsal and lateral accessory positions (Fig. 6C). Glandular cell outlets present in subdorsal, laterodorsal, sublateral, and lateroventral positions (Fig. 5A); subdorsal outlets are present consistently in all specimens, whereas presence of the others differs between individuals (Table 1). Muscle attachment sites as on preceding segment.

Segment 4 with dorsal acicular spine being slightly displaced towards paradorsal position, to same side as paradorsal spine on segment 2 . Sensory spots type 1 present in ventromedial positions (Fig. 6B-D). Sensory spots type 5 present in middorsal, paradorsal, and lateral accessory positions (Fig. 6C). Glandular cell outlets present in subdorsal and sublateral positions, and are present consistently in all specimens (Fig. 6B, C). Crescentic muscle attachment sites are present on pachycyclus in laterodorsal and ventrolateral positions (Fig. 6B); elongate attachment sites are present medially on segment in midlateral and ventromedial positions, and a pair of small and rounded attachment sites is present medially on segment in laterodorsal positions (Fig. 6B); the latter is present on this segment only, whereas the other attachment sites are repeated on the following six segments.

Segment 5 without acicular spines and sensory spots type 1, but with tubes in lateroventral positions (Figs. 5D and 7A); tubes are stout and conically tapered towards truncate tip with terminal opening; differentiation in proximal basis and distal end-piece is present, but indistinct. Sensory spots type 5 present as on preceding segment (Figs. 5C and 7C), but with the paradorsal one being unpaired and not present in all individuals (Table 1). Glandular cell outlets present in paradorsal, subdorsal, sublateral, and ventromedial positions; paradorsal outlet is unpaired, and paradorsal, subdorsal and ventromedial outlets are not present consistently in all specimens (Figs. $5 \mathrm{C}$ and $6 \mathrm{~A}-\mathrm{C}$ ). Muscle attachment sites as on segment 4, except for the small laterodorsal ones (Fig. 7A-C).

Segment 6 with dorsal acicular spine being slightly displaced towards paradorsal position, to same side as paradorsal spine on segment 3. Additional acicular spines present in lateroventral positions (Figs. 5D and 7D). Dorsal organ folds inward in the intersection between segments 5 and 6 (Fig. 7B, C). Sensory spots type 5 present in middorsal, paradorsal (Fig. 5C), lateral accessory, and ventrolateral positions; presence of midlateral sensory spots type 5 as reported by Neuhaus \& Kegel (2015) could neither be confirmed nor rejected. Glandular cell outlets present in subdorsal, sublateral, and ventromedial positions (Figs. 5C, D and 7D-F); subdorsal and ventromedial outlets are present consistently in all specimens. Muscle attachment sites as on preceding segment, but an additional pair of attachment sites appears to be present on the pachycyclus in sublateral positions.

Segment 7 with lateroventral acicular spines (Fig. 7G). Unpaired sensory spot type 1 present in paradorsal position in some, but not all specimens (Fig. 7I). Sensory spots type 5 present in middorsal, lateral accessory, and ventrolateral positions; presence of midlateral sensory spots type 5 as reported by Neuhaus \& Kegel (2015) could neither be confirmed nor rejected. Glandular cell outlets

lateral terminal spine; lvs, lateroventral spine; lvt, lateroventral tube; mdss5, middorsal sensory spot type 5 ; mlms; midlateral muscle attachment site; mls; midlateral spine; mts, midterminal spine; pdgco, paradorsal glandular cell outlet; pds, paradorsal spine; pdss $1 / 5$, paradorsal sensory spot type $1 / 5$; sdgco, subdorsal glandular cell outlet; slgco, sublateral glandular cell outlet; tsj, tergosternal junction; vlss5, ventrolateral sensory spot type 5; vmgco, ventromedial glandular cell outlet; vmss1, ventromedial sensory spot type 1 . 

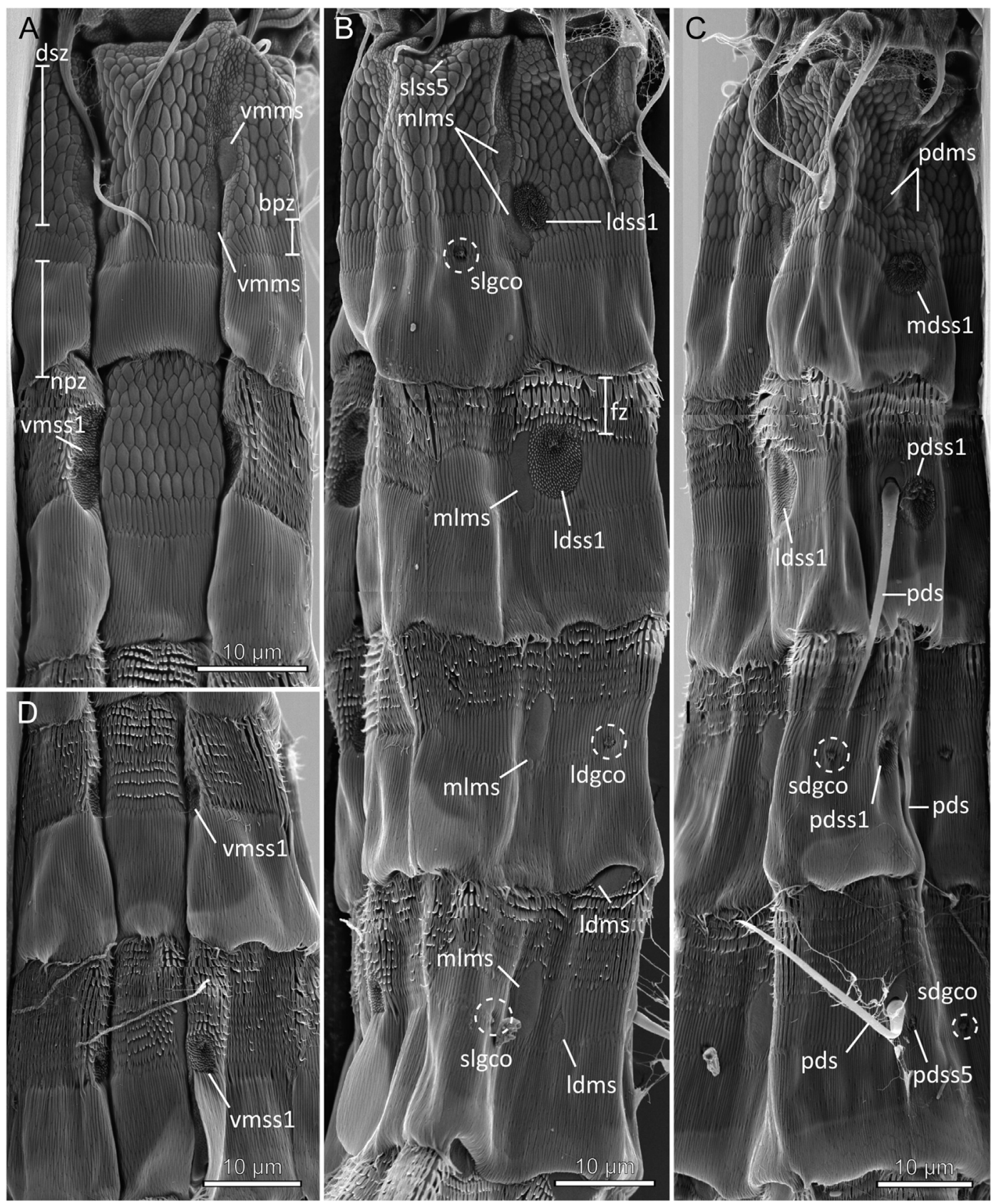

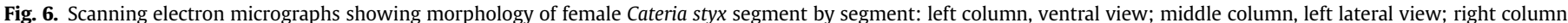

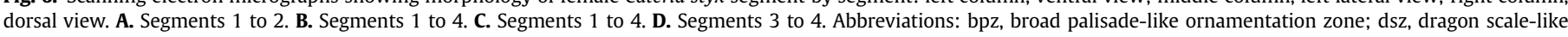

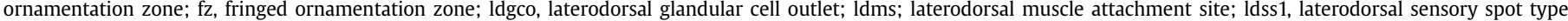

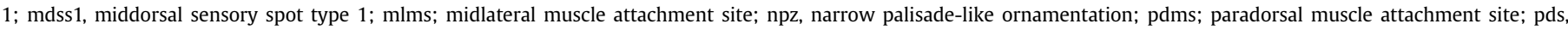

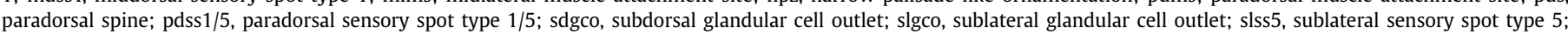
vmms; ventromedial muscle attachment site; vmss1, ventromedial sensory spot type 1 .

present in paradorsal, subdorsal, sublateral, and ventromedial positions (Figs. 5C, D and 7G-I); paradorsal outlet is unpaired (Fig. 7I), and subdorsal outlets are not present consistently in all specimens. Muscle attachment sites as on segment 5 (Fig. 7H), but with an additional pair present on the pachycyclus in subdorsal positions.

Segments 8 and 9 similar, with lateroventral acicular spines, and dorsal acicular spines being alternatingly displaced towards paradorsal positions (Figs. 5E, F, 7K, L and 8A-C); segment 8 spine to same side as paradorsal spine on segment 4 and segment 9 spine to same side as paradorsal spine on segment 6 . Unpaired sensory spot type 1 present in paradorsal position (Figs. 5E, 7L and 8C). Sensory spots type 5 present in middorsal, ventrolateral (Fig. 7K), and ventromedial positions; presence of midlateral and sublateral sensory spots type 5 as reported by Neuhaus \& Kegel (2015) could neither be confirmed nor rejected. Glandular cell outlets consistently present in subdorsal, sublateral, and ventromedial positions (Figs. 5E, F, 7J-L and 8A, B). Muscle attachment sites as on segment 7 (Figs. 7J, $\mathrm{K}$ and $8 \mathrm{~A}-\mathrm{C}$ ).

Segment 10 with dorsal acicular spine being slightly displaced towards paradorsal position, to same side as paradorsal spine on segment 8. Dorsal and lateroventral acicular spines, showing sexual dimorphism as described by Neuhaus \& Kegel (2015) 
(Figs. 5G, H and 8E, F). Paired sensory spots type 1 present in paradorsal positions (Fig. 8F). Sensory spots type 5 present in middorsal, ventrolateral (two pairs), and ventromedial positions. Glandular cell outlets present in subdorsal and sublateral positions (Fig. 8E). Muscle attachment sites as on preceding segment (Fig. 8D-F).

Segment 11 with very long lateral terminal-, lateral accessory-, and midterminal spines, and much shorter midlateral spines (Figs. 5G, H and 8G-I). Very minute sensory spots type 1 present near midterminal spine in laterodorsal positions, and as two longitudinally arranged pairs in ventromedial positions (Fig. 8G, I). Muscle attachment sites present on pachycycli in subdorsal and ventromedial positions.

\subsection{Morphology of the dorsal organ}

The dorsal organ is an elongated sickle-shaped cuticular structure situated in middorsal position in the intersegmental area between segments 5 and 6 , and only found in adults of $C$. styx (Figs. 1G and $2 \mathrm{~A}$ ). When withdrawn, the dorsal organ is tightly folded in a pocket (ca. $30 \mu \mathrm{m}$ length) situated in the anteriormost part of segment 6 , covered by the posterior edge of segment 5 (Figs. $1 \mathrm{~A}$ and $9 A)$. When everted, it extends from the anterior edge of segment 6 towards segment 5 expanding over most of the segment's dorsal surface (ca. $120 \mu \mathrm{m}$ measured from live specimens) (Figs. 1 and $9 A-E)$. In fixed specimens the dorsal cuticle of the extended organ presents tight brain-like creases in the distal part, with a longitudinal furrow in the midline, whereas the proximal part only shows deep longitudinal folds (Fig. 9E-H). Contrarily, the cuticle of the ventral side is mostly smooth (Fig. 9E). The dorsal organ seems to evert due to an increase of hydrostatic pressure caused by the contraction of the dorsoventral muscles present in most trunk segments (Figs. 1 and 10). Therefore, once the animal is fixed, the internal pressure necessary to maintain the organ turgid would disappear resulting in wrinkled extended organs measuring only ca. $35-40 \mu \mathrm{m}$ in length (Fig. 9E).

\subsubsection{Musculature associated with the dorsal organ}

F-actin staining revealed a pair of thin longitudinal muscles extending subdorsally from the pachycyclus of segment 5 along the anterior-posterior axis towards the base of the dorsal organ and attaching laterally in its left and right side (Fig. 10). The end of each of the two muscles bifurcates once inside the dorsal organ attaching anteriorly and posteriorly on each of its sides (Fig. 10A', B', $\mathrm{D}, \mathrm{E})$. The distal part of the dorsal organ lacks musculature (Fig. 10B-B', E).

\subsubsection{Innervation of the dorsal organ}

Acetylated a-tubulin-like immunoreactivity (acTub-LIR) was detected inside the proximal part of the dorsal organ, whereas the distal part seems devoid of any innervation (Fig. 11). Within the posterior half of segment 5, two to four neurites diverge from each of the two dorsal longitudinal nerves and extend posteriorly toward the proximal part of the dorsal organ converging in a small middorsal ganglion (Fig. 11A). From this ganglion the neurites extend posteriorly and connect with the dorsal longitudinal nerves on segment 6 (Fig. 11).

\section{Discussion}

\subsection{Head morphology}

\subsubsection{Previous reports on head morphology in C. styx}

The head morphology of $C$. styx was recently redescribed by Neuhaus \& Kegel (2015), but based only on LM observations. We supplemented these data with SEM observations, which enables a better interpretation of the structures, in particular on the introvert.

Our observations of the mouth cone are limited, but the morphology of the outer oral styles corresponds well with Neuhaus \& Kegel (2015). One LM specimen with an extraordinarily extended mouth cone shows a thickened ring around the mouth opening; we interpret this as a pharyngeal crown. Neuhaus \& Kegel (2015) do not report the presence of a pharyngeal crown, but its potential presence is not surprising. It appears to be a general component of the kinorhynch pharynx and has so far been reported from most other families as well, although it seems to be missing in species of Zelinkaderes (Neuhaus, 2013).

The number and arrangement of spinoscalids also fit well with the observations of Neuhaus \& Kegel (2015), even though we disagree in the ring-wise arrangement (see below). Our observations also confirm the presence of spinose processes anterior to the primary spinoscalids; however, we disagree in the reported number of hairy patches and trichoscalids. Our SEM data clearly show the presence of sixteen hairy patches, each with an associated trichoscalid, except for the patch in sector 1 . This leaves $C$. styx with sixteen hairy patches and fifteen trichoscalids. Neuhaus \& Kegel (2015) only observed fourteen patches and thirteen trichoscalids.

\subsubsection{Comparison with head morphology in C. gerlachi}

Neuhaus and Kegel's observations on $C$. gerlachi are much more detailed and include information from SEM. The morphology and arrangement of spinoscalids in C. gerlachi and C. styx are very similar. Our observations of primary spinoscalids and associated spinose processes in C. styx are nearly identical with their morphology and arrangement in C. gerlachi. We did not see internal septa in the primary spinoscalids of C. styx, as reported from C. gerlachi (Neuhaus \& Kegel, 2015). Also the morphology of spinoscalids in the following rings, as well as their sector-wise arrangement, is basically the same for the two species. We do not see the same ring-wise arrangement in C. styx as reported from C. gerlachi. However, in our opinion, a sector-wise comparison between species is more relevant than a ring-wise comparison. The ring-wise arrangement is harder to describe and much more susceptible to subjective interpretations from the individual observer. The apparent attachment point of a scalid also depends on the view angle and muscle contractions inside the head. Oppositely, the sector-wise arrangement offers a much more straightforward and objective interpretation, and is less susceptible to subjective biases. When comparing section-wise arrangements, the spinoscalids are identical in C. styx and C. gerlachi.

C. styx has the same kind of hairy patches on the posterior part of the introvert as described for $C$. gerlachi. However, as described above, $C$. styx has sixteen patches and fifteen trichoscalids, opposed to fourteen patches and thirteen trichoscalids in C. gerlachi (following Neuhaus \& Kegel 2015). The differences appear in sectors $4 / 8$ and $5 / 7$, where $C$. styx have one additional set of patches, and in sectors 4 and 8 , where $C$. styx has two long trichoscalids, opposed to only one long trichoscalid in C. gerlachi. Besides the differing numbers, the presence of hairy patches and differentiated long and short trichoscalids in the two species are striking.

The most conspicuous difference between the head morphology in C. styx and C. gerlachi is the lack of placids in C. styx. Neuhaus \& Kegel (2015) provide good documentation for the presence of differentiated, plate-like structures between the introvert and segment 1 in C. gerlachi (e.g., Fig. 6B in Neuhaus \& Kegel 2015), and they could very well be interpreted as placids. The only problem with this interpretation would be the presence of sensory spots on some these plates. No other kinorhynch is known to have sensory 

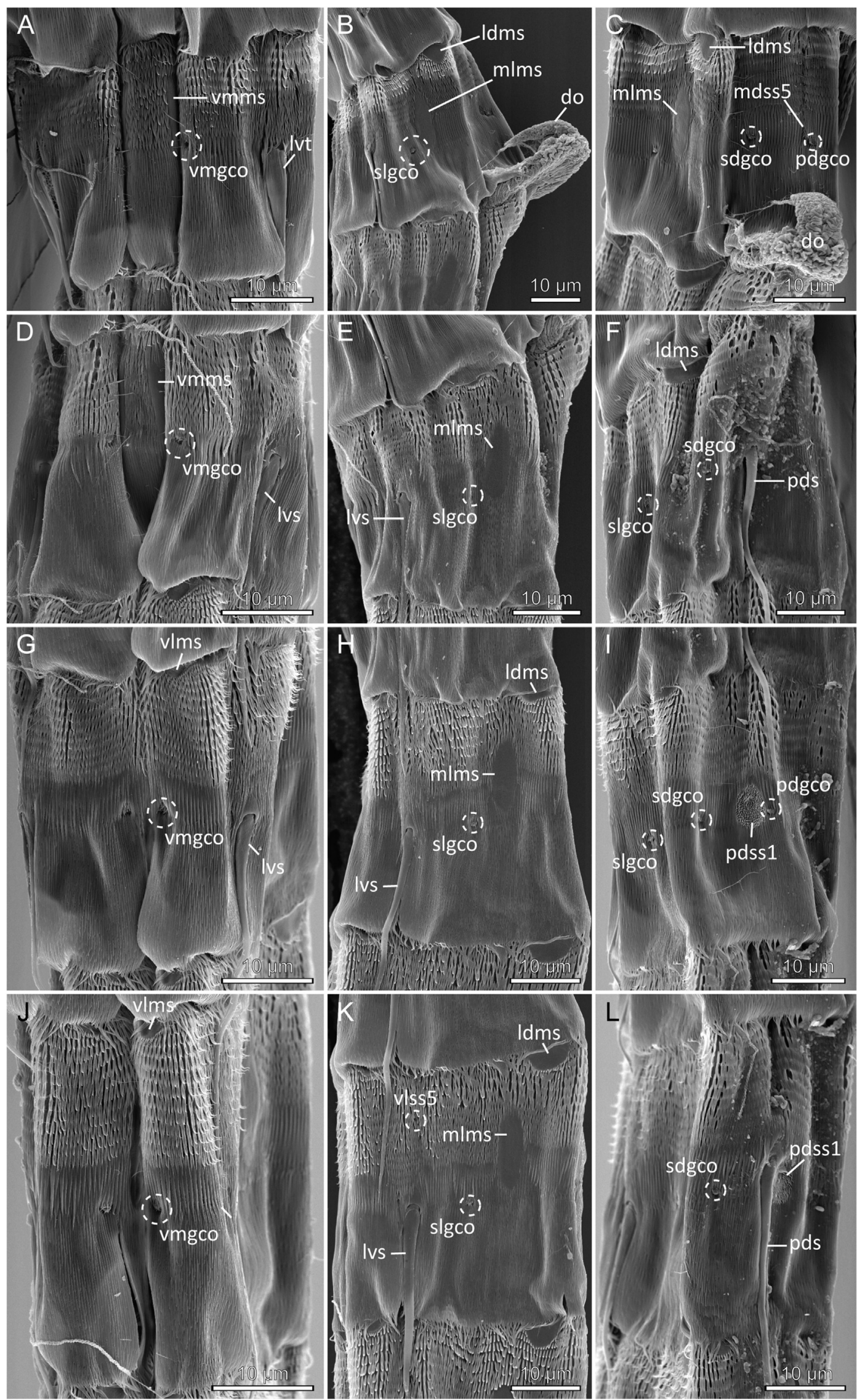


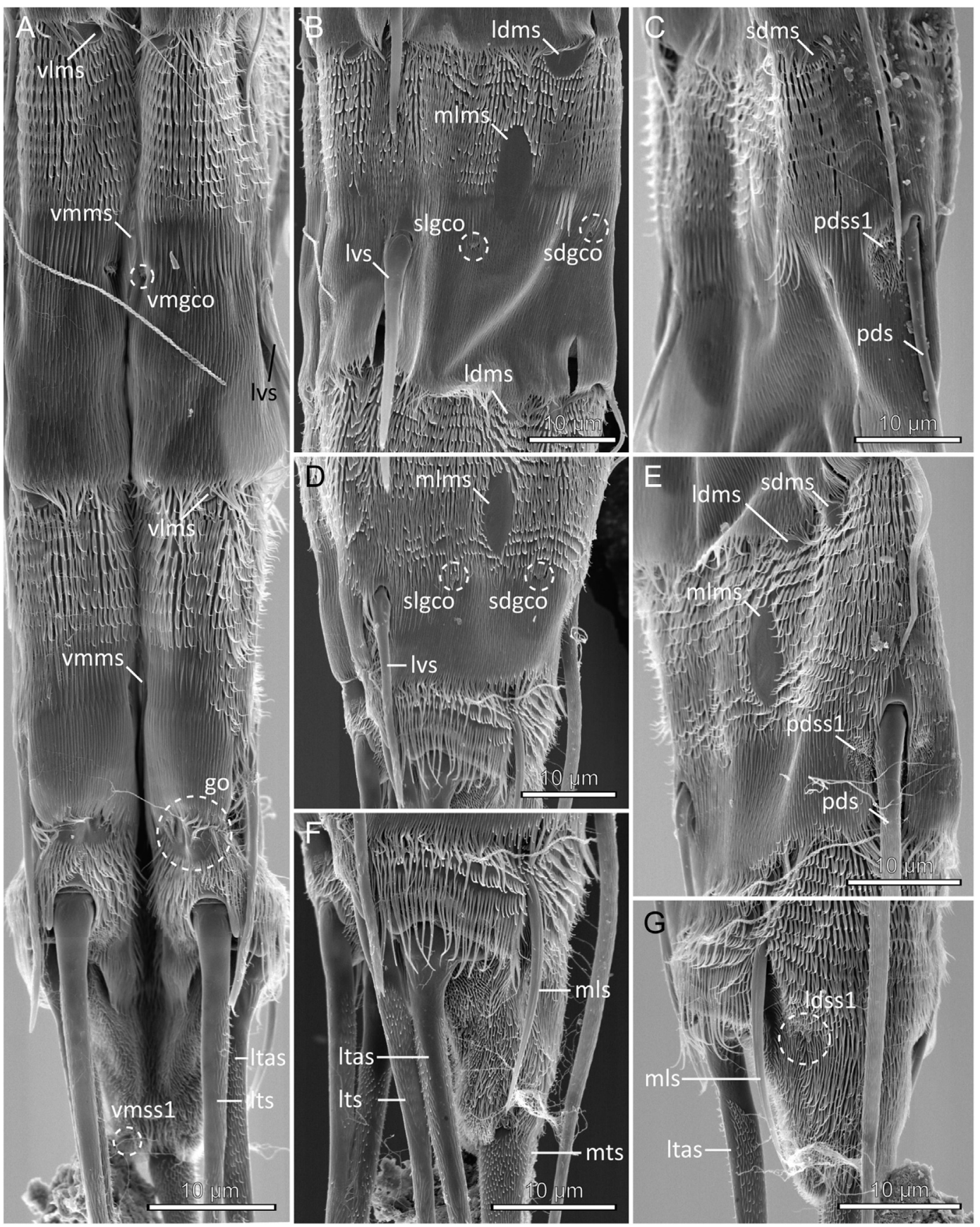

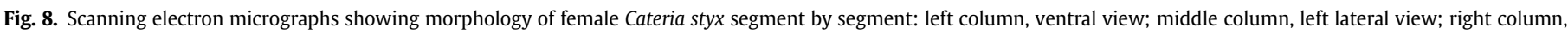

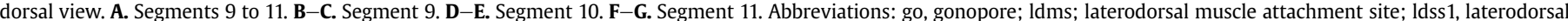

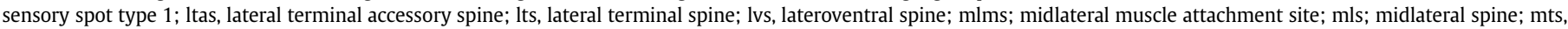

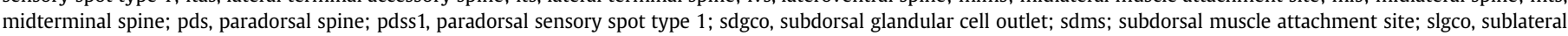

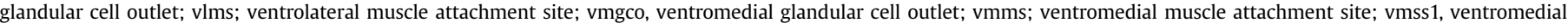
sensory spot type 1 .

spots on its placids, but if we accept that this is possible, we see no reason to doubt that the plates in $C$. gerlachi are placids. However, such plate-like structures are not present in C. styx. In specimens with fully stretched introvert, the head cuticle continues about $10 \mu \mathrm{m}$ posterior to the attachment points of the trichoscalids, and joins segment 1 at a transverse fold in the cuticle. This part of the cuticle has a fine, irregular nubbly surface, and it is clearly a part of the head cuticle without differentiation towards anything platelike. The absence of placids in $C$. styx agrees with Neuhaus and Kegel (2015) LM observations on the species.

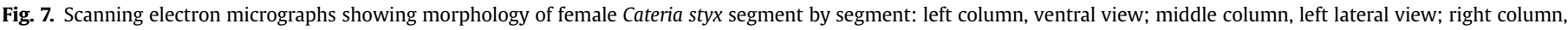

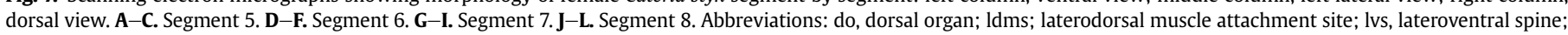

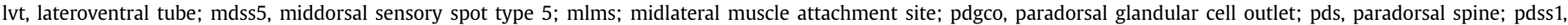

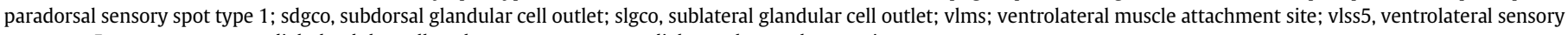
spot type 5; vmgco, ventromedial glandular cell outlet; vmms; ventromedial muscle attachment site. 
Table 1

Summary of nature and location of tubes, spines, glandular cell outlets and sensory spots arranged by series in Cateria styx.

\begin{tabular}{|c|c|c|c|c|c|c|c|c|c|c|}
\hline Position Segment & MD & PD & SD & LD & ML & SL & LA & LV & $\mathrm{VL}$ & VM \\
\hline introvert & & & ss5 & & & ss5 & & & & \\
\hline 1 & $\mathrm{ss} 1, \mathrm{~ms}$ & $\mathrm{gco}^{\mathrm{a}}, \mathrm{ms}$ & & $\mathrm{gco}^{\mathrm{a}}, \mathrm{ss} 1, \mathrm{~ms}$ & $\mathrm{~ms}, \mathrm{~ms}$ & $\operatorname{gco}^{a}$ & & $\operatorname{gco}^{a}$ & & $\mathrm{~ms}, \mathrm{~ms}$ \\
\hline 2 & ss5 & $\mathrm{ac}^{*}, \mathrm{ss} 1^{\mathrm{R}}$ & $\mathrm{ms}$ & $\mathrm{gco}^{\mathrm{a}}, \mathrm{ss} 1$ & $\mathrm{~ms}$ & $\operatorname{gco}^{a}$ & & & $\mathrm{~ms}$ & ss1 \\
\hline 3 & ss5 & $\mathrm{ac}^{*}, \mathrm{ss} 1^{\mathrm{L}}$ & gco,ms & $\mathrm{gco}^{\mathrm{a}}$ & $\mathrm{ms}$ & $\mathrm{gco}^{a}$ & ss5 & $\operatorname{gco}^{x}$ & $\mathrm{~ms}$ & ss1 \\
\hline 4 & ss5 & $\mathrm{ac}^{*}, \mathrm{ss} 5$ & gco & $\mathrm{ms}, \mathrm{ms}$ & $\mathrm{ms}$ & gco & ss5 & & $\mathrm{ms}$ & $\mathrm{ss} 1, \mathrm{~ms}$ \\
\hline 5 & ss5 & $\mathrm{ss} 5^{* \mathrm{a}}, \mathrm{gco}^{* \mathrm{ax}}$ & $\mathrm{gco}^{\mathrm{\alpha}}$ & $\mathrm{ms}$ & $\mathrm{ms}$ & gco & ss5 & tu & $\mathrm{ms}$ & $\mathrm{gco}^{\mathrm{a}}, \mathrm{ms}$ \\
\hline 6 & ss5 & $\mathrm{ac}^{*}, \mathrm{ss} 5$ & gco & $\mathrm{ms}$ & $\mathrm{ss} 5^{\#}, \mathrm{~ms}$ & $\mathrm{gco}^{\mathrm{a}}, \mathrm{ms}$ & ss5 & $\mathrm{ac}$ & $\mathrm{ss} 5, \mathrm{~ms}$ & gco,ms \\
\hline 7 & ss5 & $\mathrm{ss} 1^{* \mathrm{a}}, \mathrm{gco}^{*}$ & $\mathrm{gco}^{\mathrm{x}}, \mathrm{ms}$ & $\mathrm{ms}$ & $\mathrm{ss} 5^{\#}, \mathrm{~ms}$ & gco & ss5 & $\mathrm{ac}$ & $\mathrm{ss} 5, \mathrm{~ms}$ & gco,ms \\
\hline 8 & ss5 & $\mathrm{ac}^{*}, \mathrm{ss} 1^{*}$ & gco,ms & $\mathrm{ms}$ & $\mathrm{ss}^{\#}, \mathrm{~ms}$ & ss5 $5^{\#}$, gco & & $\mathrm{ac}$ & $\mathrm{ss} 5, \mathrm{~ms}$ & ss5,gco,ms \\
\hline 9 & ss5 & $\mathrm{ac}^{*}, \mathrm{ss} 1^{*}$ & gco,ms & $\mathrm{ms}$ & $\mathrm{ss}^{\#}, \mathrm{~ms}$ & ss5 $5^{\#}$, gco & & $\mathrm{ac}$ & $\mathrm{ss} 5, \mathrm{~ms}$ & ss5,gco,ms \\
\hline 10 & ss5 & $\mathrm{ac}^{*}, \mathrm{ss} 1$ & gco,ms & $\mathrm{ms}$ & $\mathrm{ms}$ & gco & & $\mathrm{ac}$ & $\mathrm{ss} 5, \mathrm{ss} 5, \mathrm{~ms}$ & $\mathrm{ss} 5, \mathrm{~ms}$ \\
\hline 11 & mts & & $\mathrm{ms}$ & ss1 & $\mathrm{ac}$ & & ltas & lts & & $\mathrm{ss} 1, \mathrm{ss} 1, \mathrm{~ms}$ \\
\hline
\end{tabular}

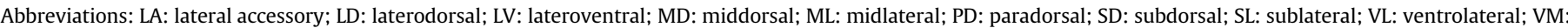

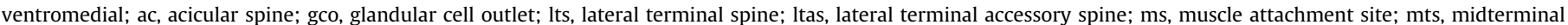

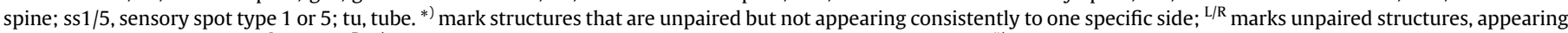

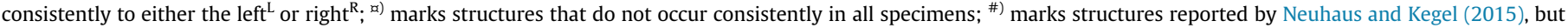
where the present study could neither confirm nor reject their presence.

\subsubsection{Functional morphology of the neck region}

The lack of placids and a well-differentiated neck region, combined with the presence of extraordinary long primary spinoscalids, preclude $C$. styx from doing a complete retraction of the head, with subsequent closing of the head opening. Even if the species was equipped with a proper closing apparatus, the length of the primary spinoscalids would still represent a problem and require that the introvert was retracted extremely deep into the trunk. The attachment sites for the introvert retractor muscles are located midlaterally in segments $4-6$ which prevents the introvert from being retracted deep enough; therefore, the tips of the spinoscalids would always stick out of the head opening making a fully functional closing apparatus redundant. It is unclear if an animal with the strongest possible retraction of the head actually also retracts the anterior part of segment 1 , or whether this is an artefact due to fixation. It is clear however, that at least the mouth cone and introvert can be fully retracted to the level around the trichoscalids, leaving only the distal parts of the spinoscalids to stick out (Supplementary file 1 ). We suggest that the animal, at this level of retraction, uses the circular muscles in the posterior part of the introvert to close tightly around the projecting scalids. The hairy patches behind the scalids could play a function in making this closing even tighter, as the hairs would be pressed, in a nearly Velcro-like manner against the tightly wrapped scalids.

\subsubsection{Comparison with head morphology in other species}

Neuhaus \& Kegel (2015) provided a quite thorough discussion and comparison of the morphology of head structures in Cateria with those of other kinorhynch species, hence, it would be redundant to repeat these points here. Instead of focusing on the morphology of the head structures, we will address the scalid arrangement in Cateria.

Compared to most kinorhynchs, species of Cateria have a very low number of scalids. Besides the ten primary spinoscalids, both Cateria species have only 35 spinoscalids (Neuhaus \& Kegel 2015, Fig. 4 in present contribution). Table 2 summarizes the available SEM data for the number of spinoscalids among kinorhynchs (primary spinoscalids are not counted because the number is fixed at 10 in all species). The summary shows that the highest numbers of spinoscalids are found among species within the Echinoderidae that reaches 90 or more in some species. Outside Echinoderidae, the number of spinoscalids is constant around 60-67 in both the Allomalorhagida and the two remaining orders of Cyclorhagida; a spinoscalid number of 65 seems to be frequent. The only other genus with a considerably lower number of spinoscalids is
Zelinkaderes, with 45 spinoscalids in Zelinkaderes brightae Sørensen et al., 2007, Zelinkaderes klepali Bauer-Nebelsick, 1995 and Zelinkaderes yong Altenburger et al., 2015, and only 30 in Z. floridensis Higgins, 1990 (Altenburger et al. 2015; Bauer-Nebelsick 1995; Higgins 1990; Sørensen et al. 2007). In the descriptions of $Z$. brightae and Z. yong, the authors show that the lower number of spinoscalids are due to a lack of spinoscalids in the anterior part of the introvert, and demonstrate that either anlagen or remains of reduced spinoscalids are present in Rings 02 and 03 in shape of fringe-like structures (Altenburger et al. 2015; Sørensen et al. 2007). In contrast, the spinoscalids of the anterior rings are fully developed in $C$. styx and $C$. gerlachi, while scalids are missing in the posterior part of the introvert and replaced by hairy patches. Even though a reduced number of spinoscalids is present in species of Cateria and Zelinkaderes, we do not infer that this condition was present in their most recent common ancestor. Instead, we infer that the loss of spinoscalids occurred independently, and that Cateria lost its more posterior scalid rings, whereas Zelinkaderes reduced the scalids in its more anterior rings.

Another kinorhynch with low number of spinoscalids is a new species and genus that is currently being described (see Yamasaki 2019). According to Yamasaki 2019, the new species and genus is closely related with Franciscideres kalenesos Dal Zotto et al., 2013 and it has only 30 fully developed spinoscalids plus 20 scalids where only the basal sheath is developed. Similar to species of Cateria, the new species and genus has a reduced number scalids, and the scalids are restricted to the anterior rings of the introvert. This could suggest a closer relationship between the new genus and Cateria, but information on the scalid pattern and distribution in $F$. kalenesos would obviously be desirable to either support or reject this.

\subsection{Morphology of cuticular trunk structures}

\subsubsection{Cuticular trunk ornamentation}

The cuticular ornamentation in C. styx is unique, and despite their close relationship, it even differs considerably from the ornamentation in its congener, C. gerlachi. Comparison of cuticular ornamentation in kinorhynchs requires thorough documentation from SEM. Because Neuhaus \& Kegel (2015) provided this documentation for $C$. gerlachi, we are now able to make direct comparisons with our SEM data from C. styx.

The most conspicuous and unique feature in C. styx is the dragon scale-like ornamentation on segments 1 and 2, formed by hexagonal elements. Such structures are not present in C. gerlachi, which 

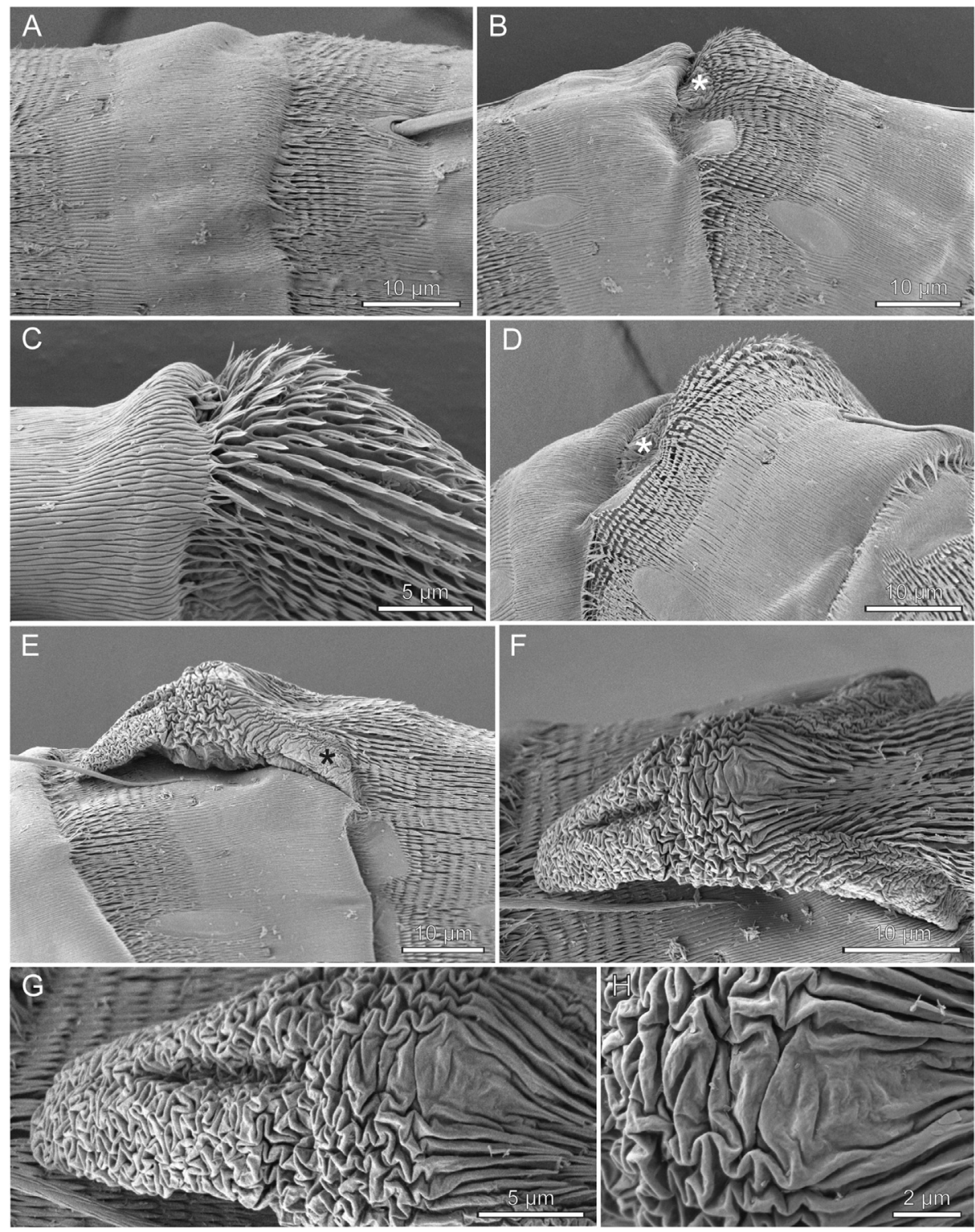

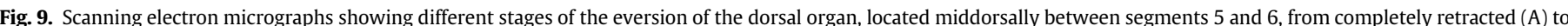

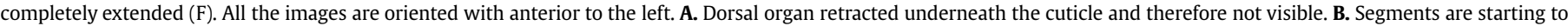

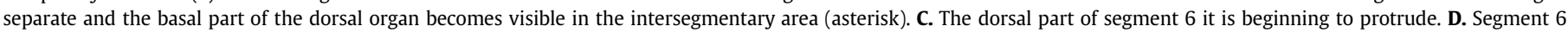

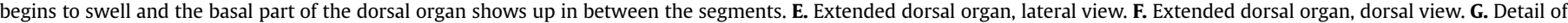
the anterior cuticular folds on the dorsal organ. $\mathbf{H}$. Details of the cuticular folds of the posterior part of the dorsal organ.

instead has areas with either fringed patches, or nearly smooth cuticle. $C$. gerlachi has two fringed patches on the anterior half of segment 1 , one covering the tergal plate, from midlateral to midlateral positions, and one covering the midsternal plate.

On the posterior half of segment 1 , as well as the following segment, $C$. styx has broad and narrow palisade-like ornamentation. Again, a different pattern is found in C. gerlachi, which has very minute lanceolate scales. Every second row of scales is slightly shifted in position, so that the tips of the scales in the anterior row fill the space between the scales in the following. This arrangement resembles the dragon scale-like ornamentation in $C$. styx, but the scales in this species are larger and hexagonal rather than lanceolate.

The anterior parts of segments 2 to 10 in C. gerlachi have transverse rows of fringe-like bifurcated hairs (termed secondary fringes by Neuhaus \& Kegel 2015), which resembles the arrangement in C. styx. The ornamentation of the posterior segment halves differs though, with $C$. styx having palisade-like ornamentation and $C$. gerlachi having either lanceolate scales or very minute spinose hairs.

No other kinorhynch species has a surface ornamentation that resembles $C$. styx. The potential close relative $F$. kalenesos has a rather homogenous covering of lanceolate hairs on all segments (Dal Zotto et al. 2013). This resembles to some extent the ornamentation on the posterior segment halves in $C$. gerlachi, but this pattern is not found in C. styx. Other potentially close relatives of Cateria are the species within the Zelinkaderidae, but again we find a completely different cuticular ornamentation. Triodontoderes anulap Sørensen \& Rho, 2009 has secondary fringes with very short, pointed hairs, and large leaf-like hairs on the posterior parts of its segments (Sørensen \& Rho 2009), and in species of Zelinkaderes the minute hairs are typically arranged in 

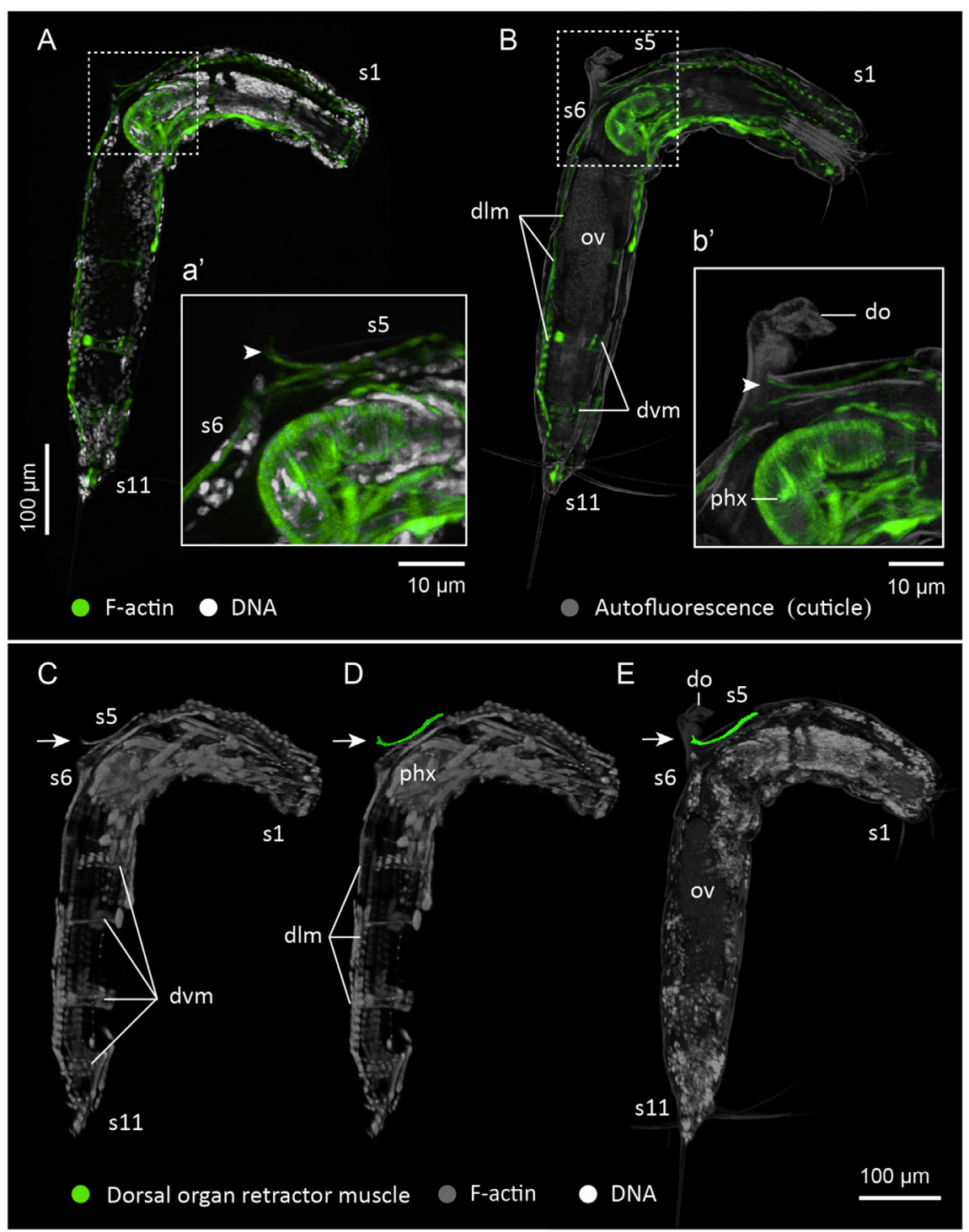

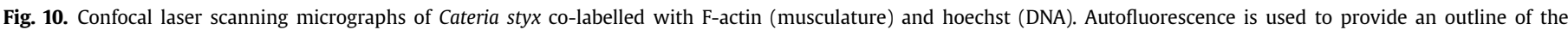

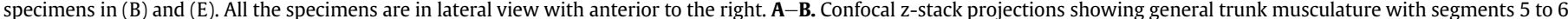

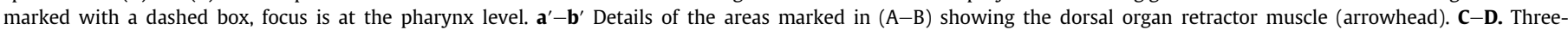

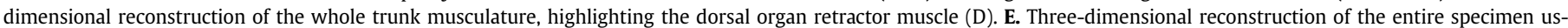

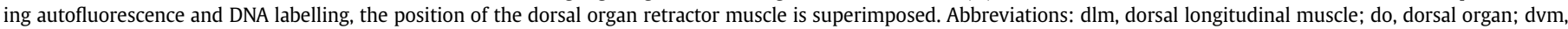

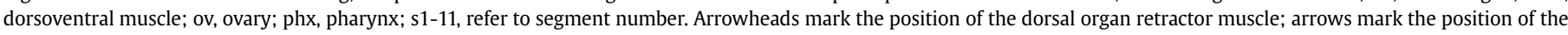
dorsal organ.

conspicuous longitudinal lines (e.g., Altenburger et al. 2015; Bauer-Nebelsick 1995; Higgins 1990; Sørensen et al. 2007). One might speculate if the cuticular ornamentation in C. styx is a habitat adaptation, rather than a trait of phylogenetic significance, but it also differs considerably from other beach- and sand dwelling kinorhynch species. Beach inhabiting kinorhynchs include Cephalorhyncha flosculosa Yildiz et al., 2016, Cephalorhyncha liticola Sørensen, 2008, C. nybakkeni (Higgins, 1986), but these species show a rather typical echinoderid cuticle ornamentation with bracteate cuticular hairs (Higgins 1986; Sørensen 2008; Yildiz et al. 2016).

\subsubsection{Cuticular trunk structures - comparison with results of} Neuhaus \& Kegel (2015)

Our observations confirm to a great extent the LM observations on C. styx provided by Neuhaus \& Kegel (2015). The main differences include (1) structures either observed in the present study but missed by Neuhaus \& Kegel (2015) or vice versa; (2) structures observed in both studies, but where we disagree about the nature of the structure; and (3) structures observed in both studies, but where we disagree about the exact position of the structure.

Disagreements about the exact positions of certain structures are restricted to the three anterior segments, where we see the large muscle attachment sites as midlateral, meaning that some of the structures reported as midlateral by Neuhaus \& Kegel (2015) are interpret as either more dorsal or more ventral. In the specimens examined in this study, we found glandular cell outlets on segment 1 (paradorsal, laterodorsal, and sublateral), segment 5 (ventromedial), segment 6 (sublateral), and segment 7 (ventromedial), that were not reported by Neuhaus \& Kegel (2015). However, this study has also shown that the occurrence of 

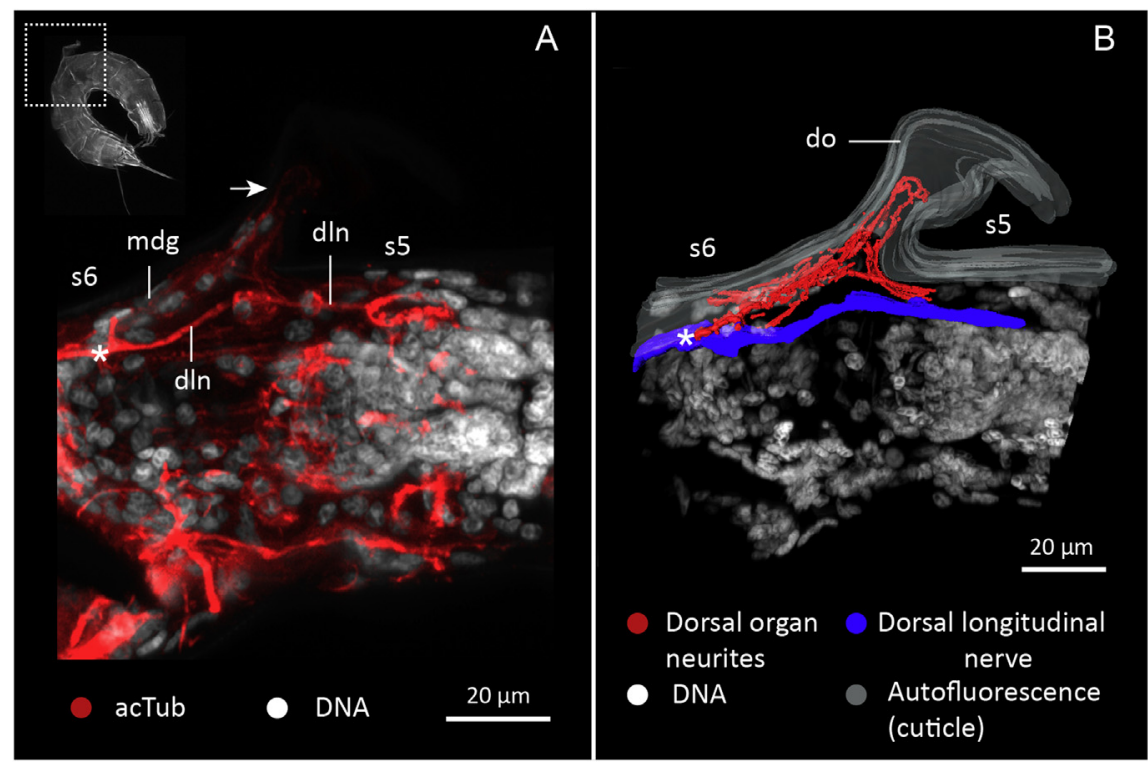

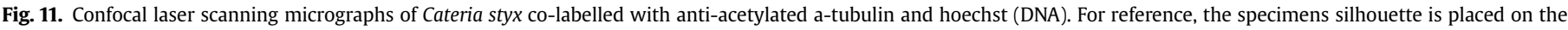

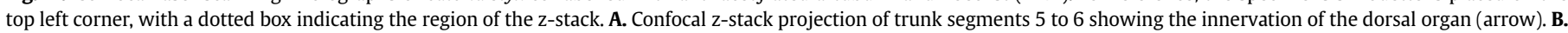

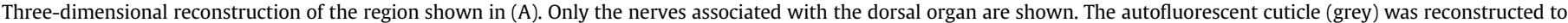

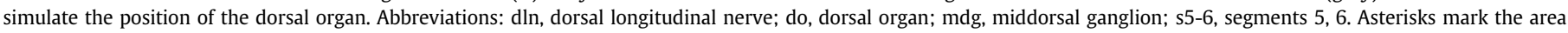
where the dorsal organ neurites connect with the dorsal longitudinal nerve.

glandular cell outlets varies to a great extent at the individual level, so the different observations in the two studies most likely reflect this variation.

We found a pair of sublateral sensory spots type 5 on the posterior part of the introvert that was missed in the description of Neuhaus \& Kegel (2015). By contrast, Neuhaus \& Kegel (2015) observe some sensory spots type 5 on segments 6 to 9 that we did not observe in the present study. We also have different interpretations of two pairs of sensory spots type 5 reported by Neuhaus \& Kegel (2015). They reported the presence of a midlateral sensory spot type 5 on segment 4 , but also seemed to be slightly uncertain about the nature of this structure. We are quite certain that this structure is the small additional muscle attachment site that we see in laterodorsal position on this segment, close to the much larger midlateral muscle attachment site. Neuhaus \& Kegel (2015) also report the presence of a subdorsal sensory spot type 5 on segment 9, but our SEM data suggests that this is a glandular cell outlet.

We finally disagree with Neuhaus \& Kegel (2015) about the interpretations of the sensory structures on the terminal segment. Neuhaus \& Kegel (2015) report the presence of sensory spots type 3 at the base of the midterminal spine. We agree that the minute, paired projections at the base of the spine resemble sensory spots type 3 in LM, and that this kind of sensory spots typically is found in this position in most kentrorhagids, but in SEM we see no sensory spots type 3 in these positions. Instead, we simply see a pair of cuticular projections, but on the ventral side of these projections we actually find two pairs of very minute, longitudinally arranged sensory spots type 1 .

Despite these differences, the overall picture is that our observations fit well with those reported by Neuhaus \& Kegel (2015), and that the most important conclusion is that the presence and precise location of glandular cell outlets show great variation at the individual level. Hence, these structures should not be taken too much into account in taxonomic comparison. More importantly, despite their variation, the glandular cell outlets always appear in high numbers, which, as addressed below, may play a major role in counteracting against the species' extreme hydrophobicity.

\subsubsection{Paradorsally displaced spines}

The dorsal spines in C. styx are not perfectly middorsally aligned as in other cyclorhagid kinorhynchs. Instead, they are slightly laterally displaced to alternatingly left or right side. This lateral displacement of spines to a paradorsal position is most commonly known from species of Dracoderes, where the displacement is very conspicuous (e.g., Higgins \& Shirayama 1990; Sørensen et al. 2012a; Thomsen et al. 2013). The lateral displacement in C. styx is far from being as distinct in Dracoderes, but the displacement is nevertheless evident. This lateral displacement of dorsal spines is highly relevant in light of the finding and description of a new allomalorhagid genus, and putative sister group to Franciscideres (Yamasaki, 2019). In the description of this new genus, Yamasaki 2019 notes that it also has its dorsal spines slightly laterally displaced to alternatingly left or right side. The finding of the same condition in the new genus of Yamasaki 2019 and C. styx prompted a reexamination of the types of $F$. kalenesos, and this showed that also this species has laterally displaced dorsal spines.

Dracoderes and Franciscideres were recently shown to belong to the kinorhynch class Allomalorhagida, together with the morphologically different pycnophyid and neocentrophyid kinorhynchs (Sørensen et al. 2015). This analysis also suggested that Cateria was a kentrorhagid genus, belonging to the other kinorhynch class Cyclorhagida, but Sørensen et al. (2015) discussed that future analyses very likely could show that Cateria was much more closely related with Franciscideres, and perhaps should be seen as an allomalorhagid genus. The finding of dorsal spines being alternatingly laterally displaced, to a high degree in Dracoderes and to a smaller degree in C. styx, F. kalenesos, and the new species and genus of Yamasaki 2019, could indeed suggest that Cateria belongs to the Allomalorhagida, and eventually turn out to be a synapomorphic character for these genera.

\subsection{Functional morphology of the dorsal organ}

The first report of the dorsal organ was included and illustrated in the original description of $C$. styx, and defined as a "protrusible sack" with an unknown function (Gerlach 1956). Subsequent 
Table 2

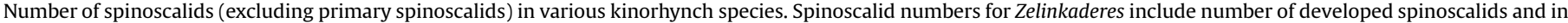

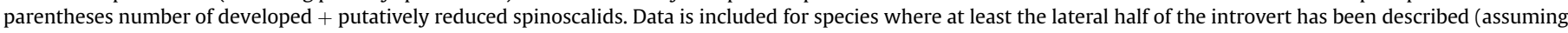
that the complete introvert display bilateral symmetry), but data is excluded for species where number of spinoscalids in the most posterior rings was uncertain.

\begin{tabular}{|c|c|c|c|c|}
\hline Class/order & Family & Species & Spinoscalids & Reference \\
\hline \multicolumn{5}{|c|}{ Allomalorhagida } \\
\hline & \multirow[t]{3}{*}{ Dracoderidae } & & 67 & \\
\hline & & Dracoderes abei Higgins \& Shirayama, 1990 & 67 & Sørensen et al. (2012a) \\
\hline & & D. gallaicus Sørensen et al., 2012 & 67 & Sørensen et al. (2012a) \\
\hline & \multirow[t]{3}{*}{ Neocentrophyidae } & & 65 & \\
\hline & & Paracentrophyes anurus Sørensen et al., 2010 & 65 & Sørensen et al. (2010a) \\
\hline & & P. sanchezae Sørensen \& Landers, 2017 & 65 & Sørensen and Landers (2017) \\
\hline & \multirow[t]{8}{*}{ Pycnophyidae } & & $63-65$ & \\
\hline & & Cristaphyes cristatus (Sánchez et al., 2013) & 63 & Sánchez et al. (2013) \\
\hline & & C. glaurung Sørensen \& Grzelak, 2018 & 63 & Sørensen and Grzelak (2018) \\
\hline & & C. scatha Sørensen \& Grzelak, 2018 & 65 & Sørensen and Grzelak (2018) \\
\hline & & Krakenella smaug (Sánchez et al., 2013) & 65 & Sánchez et al. (2013) \\
\hline & & Leiocanthus chalgap (Sánchez et al., 2013) & 63 & Sánchez et al. (2013) \\
\hline & & L. lageria (Sánchez et al., 2014) & 64 & Sánchez et al. (2014) \\
\hline & & Pycnophyes ancalagon Sørensen \& Grzelak, 2018 & 65 & Sørensen and Grzelak (2018) \\
\hline \multicolumn{5}{|c|}{ 20 } \\
\hline \multicolumn{5}{|c|}{ Echinorhagata } \\
\hline & \multirow[t]{25}{*}{ Echinoderidae } & & $65-92$ & \\
\hline & & Cephalorhyncha liticola Sørensen, 2008 & 67 & Sørensen (2008) \\
\hline & & Echinoderes antalyaensis Yamasaki \& Durucan, 2018 & 66 & Yamasaki \& Durucan, 2018 \\
\hline & & E. applicitus Ostmann et al., 2012 & 90 & Ostmann et al., 2012 \\
\hline & & E. augustae Sørensen \& Landers, 2014 & 72 & Sørensen and Landers (2014) \\
\hline & & E. bookhouti Higgins, 1964 & 81 & Sørensen et al. (2016) \\
\hline & & E. capitatus Zelinka, 1928 & 75 & Nebelsick (1993) \\
\hline & & E. cernunnos Sørensen et al., 2012 & 73 & Sørensen et al. (2012b) \\
\hline & & E. hamiltonorum Sørensen et al., 2018 & 72 & Sørensen et al. (2018) \\
\hline & & E. hviidae Sørensen et al., 2018 & 72 & Sørensen et al. (2018) \\
\hline & & E. lupherorum Sørensen et al., 2018 & 72 & Sørensen et al. (2018) \\
\hline & & E. marthae Sørensen, 2014 & 92 & Sørensen (2014) \\
\hline & & E. microaperturus Sørensen et al., 2012 & 73 & Sørensen et al. (2012b) \\
\hline & & E. ohtsukai Yamasaki \& Kajihara, 2012 & 84 & Herranz and Leander (2016) \\
\hline & & E. pennaki Higgins, 1960 & 75 & Herranz et al. (2018) \\
\hline & & E. pterus Yamasaki et al., 2018 & 66 & Yamasaki et al. (2018) \\
\hline & & E. riceae Herranz et al., 2014 & 90 & Herranz et al. (2014) \\
\hline & & E. spinifurca Sørensen et al., 2005 & 74 & Sørensen and Pardos (2008) \\
\hline & & E. tchefouensis Lou, 1934 & 73 & Sørensen et al. (2012b) \\
\hline & & E. yamasakii Sørensen et al., 2018 & 72 & Sørensen et al. (2018) \\
\hline & & Fissuroderes sorenseni Herranz \& Pardos, 2013 & 86 & Herranz and Pardos (2013) \\
\hline & & Meristoderes boylei Herranz \& Pardos, 2013 & 90 & Herranz and Pardos (2013) \\
\hline & & M. herranzae Sørensen et al., 2013 & 68 & Sørensen et al. (2013) \\
\hline & & M. macracanthus Herranz et al., 2012 & 76 & Herranz et al. (2012) \\
\hline & & Polacanthoderes martinezi Sørensen, 2008 & 65 & Sørensen (2008) \\
\hline \multicolumn{5}{|c|}{ Kentrorhagata } \\
\hline & \multirow[t]{5}{*}{ Antygomonidae } & & 65 & \\
\hline & & Antygomonas caeciliae Dal Zotto, 2015 & 65 & Dal Zotto (2015) \\
\hline & & A. incomitata Nebelsick, 1990 & 65 & Sørensen et al. (2009) \\
\hline & & A. oreas Bauer-Nebelsick, 1996 & 65 & Bauer-Nebelsick (1996) \\
\hline & & A. paulae Sørensen, 2007 & 65 & Sørensen (2007) \\
\hline & \multirow{3}{*}{ Cateriidae } & & 35 & \\
\hline & & Cateria gerlachi Higgins, 1968 & 35 & Neuhaus and Kegel (2015) \\
\hline & & C. styx Gerlach, 1956 & 35 & Present study \\
\hline & Centroderidae & & $60-66$ & \\
\hline & & Centroderes barbanigra Neuhaus et al., 2014 & 66 & Neuhaus et al. (2014) \\
\hline & & C. bonnyae Neuhaus et al., 2014 & 66 & Neuhaus et al. (2014) \\
\hline & & C. drakei Neuhaus et al., 2014 & 66 & Neuhaus et al. (2014) \\
\hline & & C. readae Neuhaus et al., 2014 & 65 & Neuhaus et al. (2014) \\
\hline & & C. spinosus Reinhard, 1881 & 65 & Neuhaus et al. (2013) \\
\hline & & Condyloderes megastigma Sørensen et al., 2010 & 60 & Sørensen et al. (2010b) \\
\hline & Semnoderidae & & $64-65$ & \\
\hline & & Semnoderes armiger Zelinka, 1928 & 65 & Sørensen et al. (2009) \\
\hline & & Sphenoderes aspidochelone Sørensen \& Landers, 2018 & 64 & Sørensen and Landers (2018) \\
\hline & Zelinkaderidae & & $30-60(75)$ & \\
\hline & & Triodontoderes anulap Sørensen \& Rho, 2009 & 60 & Sørensen and Rho (2009) \\
\hline & & Zelinkaderes brightae Sørensen et al., 2007 & $45(75)$ & Sørensen et al. (2007) \\
\hline & & Z. floridensis Higgins, 1990 & $30(?)$ & Higgins (1990) \\
\hline & & Z. klepali Bauer-Nebelsick, 1995 & $45(?)$ & Bauer-Nebelsick (1995) \\
\hline & & Z. yong Altenburger et al., 2015 & $45(65)$ & Altenburger et al. (2015) \\
\hline & Incertae sedis & Tubulideres seminoli Sørensen et al., 2007 & 65 & Sørensen et al. (2007) \\
\hline & & Wollunquaderes majkenae Sørensen \& Thormar, 2010 & 65 & Sørensen and Thormar (2010) \\
\hline Xenosomata & Campyloderidae & & 65 & \\
\hline & & Campyloderes cf. vanhoeffeni Zelinka, 1913 & 65 & Neuhaus and Sørensen (2013) \\
\hline & & Ryuguderes iejimaensis Yamasaki, 2016 & 65 & Yamasaki (2016) \\
\hline
\end{tabular}


studies by Higgins (1968) and Neuhaus \& Kegel (2015) also reported the presence of the dorsal organ; however, its potential function was never addressed. Live observations combined with new morphological data have allowed us to scrutinize the dorsal organ further and make inferences about its utility. There are several facts that have guided our interpretations on the organ function: (i) the eversion process; (ii) the presence of associated muscles; (iii) the presence of innervation; (iv) the presence of distinct cuticular folds.

Live observations of $C$. styx have provided information to understand the eversion of the dorsal organ. It seems clear that the dorsal organ everts due to an increase of the internal pressure of the trunk produced by the contraction of the dorsoventral muscles present in most of the segments. During this process, the dorsal organ slowly emerges, reaching a point after which it rapidly unfolds and inflates extending to its full size (Figs. 1 and 9; Supplementary file 2). The speed of the eversion demonstrates that there is no direct muscular action involved, but a progressive increase of internal pressure (Fig. 1).

The muscles associated with the dorsal organ are interpreted to be retractors due to their orientation and attachment points. The anterior attachments of the dorsal organ retractors are situated on the pachycyclus of segment 5 , while the posterior attachments are in the basal part of the dorsal organ (Fig. 10). This arrangement not only makes sense for a retracting motion but it is also congruent with the position of the withdrawn organ underneath segment 5 (Fig. 1). The retraction of the dorsal organ has not been observed in live specimens; however, we suggest it would occur after a decrease of the internal pressure of the trunk by relaxation of the dorsoventral muscles which would deflate the organ. Subsequent contraction of the dorsal organ retractor muscles will pull the dorsal organ from its base inwards towards segment 5 . An alternative scenario that would explain the presence of muscles in the base of the dorsal organ would be that the high pressure created when the dorsal organ everts could break the trunk longitudinal muscles. This would mean that the dorsal organ cannot be retracted. However, we could observe intact longitudinal muscles adjacent to the muscles associated with the dorsal organ (Fig. 10) which disproof this hypothesis.

The presence of several neurites innervating the proximal part of the dorsal organ and converging in a middorsal ganglion on segment 6 might be related with the control of the inflationdeflation process and coordination of the retractor muscles action.

The dorsal organ exhibits a complex surface ornamentation that differs from the proximal to the distal area. The proximal area shows longitudinal folds, whereas the distal part shows very convoluted brain-like creases and a longitudinal furrow. In order to fit in the small cuticular pocket when retracted, the dorsal organ has to decrease approximately four times its size (from ca. $120 \mu \mathrm{m}$ to ca. $30 \mu \mathrm{m}$ ). This way, the cuticle is required to be tightly packed, which explains the presence of the multiple wrinkles. The longitudinal furrow indicates that the dorsal organ folds along the left-right axis while the brain-like wrinkles help the dorsal organ to reduce its volume and collapse along an anterior-posterior axis occupying a minimum space. The ventral side of the dorsal organ is smooth, indicating that the cuticle only expands towards the dorsal side.

Based on these details we conclude that the dorsal organ in C. styx is a hydrostatic, retractable structure with sensorial capabilities formed as a specialization of the intersegmental soft cuticle of segments 5 and 6 . The absence of a pore in the dorsal organ excludes any potential chemoreceptory or secretory function leaving the mechanoreception as a plausible option. The presence of the organ in both males and females, also reported by Neuhaus \& Kegel (2015), and the absence of connection with gonad tissue excludes a copulatory function.
The fact that $C$. stys abundances were higher a few meters below the high tide mark than closer to the water line suggest a preference for a specific habitat that is greatly influenced by heavy rains and groundwater inflow. In this habitat, salinity fluctuations can be abrupt and unpredictable and the dorsal organ could be interpreted as an extra osmoregulatory structure to acclimate to such conditions. However, several other kinorhynch species that live in intertidal areas with similar "salinity stress" (including its congener C. gerlachi) lack a dorsal organ, which weakens this hypothesis.

Another possibility is that the dorsal organ could act as an adhesive structure or adhesive pad used to attach $C$. styx to the sediment. This hypothesis is supported by live observations where the animals were extremely sticky, and would adhere to any surface, especially through the dorsal organ when everted. The absence of any secretion associated with the organ eversion means that the adhesion would be mechanical, most likely through friction. Moreover, the fact that the dorsal organ is flexible and has an elaborated cuticular microstructure only on its dorsal side would be congruent with the adhesion, as it will adjust to the topography of the sediment grains, as it enlarges and increases the friction against the sediment. This way $C$. styx, which lives in intertidal areas influenced by changing water flow and high risk of desiccation, could avoid drifting or being dragged to the surface by attaching to sediment particles. Similarly, using the same attachmentdetachment method (assuming that detachment occurs with the deflation and retraction of the dorsal organ) they could control dispersion.

The dorsal organ in C. styx is a unique structure among kinorhynchs. However, similar adhesive inflatable structures have been described from other animal groups equipped with a hard cuticle. This is the case for the tardigrades Batillipes bullacaudatus McGinty \& Higgins, 1968 and Tanarctus bubulubus Jørgensen \& Kristensen, 2001. Both species were described as having specialized caudal appendages with balloon-like projections (Jørgensen \& Kristensen 2001; McGinty \& Higgins 1968). In T. bubulubus these balloons are hollow and strongly furrowed and are hypothesized to be either buoyant or adhesive organs (Jørgensen \& Kristensen 2001). Many arthropod groups such as arachnids and insects, also show a wide variety of inflatable and adhesive soft protuberances, called "arolia", which are extended by internal hemolymph pressure and can be retracted by a flexor muscle. These structures are normally localized in the legs as, e.g., in scorpion prenymphs to attach to their mother's back (Wolf \& Gorb 2016). However, they have also been described in the anal region in some parasitic species of mites, utilized to attach to their hosts (Wolf \& Gorb 2016).

\subsection{Hydrophobicity and adhesion}

All kinorhynchs have a chitinous hydrophobic cuticle. This characteristic has been used as an advantage to facilitate their extraction from any type of sediment through the "bubble and blot" method (Higgins 1988; Sørensen \& Pardos 2008). However, cuticular hydrophobicity seems to be extremely inconvenient when living in an aquatic environment where the risk of being trapped in air bubbles is very high. In spite of this, our live observations detected an extremely high hydrophobicity in extracted C. styx specimens, which remained in the water surface and were very difficult to submerge again. Ishii et al. (2016) studied the wettability of the intertidal kinorhynch Echinoderes komatsui Yamasaki \& Fujimoto, 2014 and concluded that the species, in order to reduce the hydrophobicity of its cuticle, produces a hydrophilic mucous coat that can disappear due to disturbances such as those generated during the extraction process. Following the same reasoning, we could assume that $C$. styx would turn hydrophobic immediately after extraction because it had lost its hydrophilic mucus coat. 
However, over time, we did not find evidence of the production of a hydrophilic mucus layer in live specimens nor a change in the high hydrophobicity of their cuticle.

C. styx specimens are extraordinary sticky both live and fixed. Live observations on C. gerlachi by Rao \& Ganapati (1966) also described how the specimens adhere firmly to the substrate. Adhesion can be produced by chemical or mechanical means. Chemical methods involve the secretion of sticky substances (e.g., polymers and colloids), usually through specific glands (Giere 2009; Gorb 2008); whereas mechanical methods rely on specialized surfaces or rigid structures (e.g., spines, hairs, hooks) that interlock with substrate protuberances generating friction (Ditsche \& Summers 2014; Gorb 2008).

Chemical adhesive methods are very common in meiofaunal groups, which need to attach to the substrate to avoid drifting but still maintain a mobile lifestyle (Lengerer \& Ladurner 2018). These methods are usually associated with the presence of a duo-gland adhesive and release system, as present in, e.g., gastrotrichs, rotifers, and flatworms (Giere 2009; Lengerer \& Ladurner 2018), but lacking in kinorhynchs. Most kinorhynch species show numerous glandular, mucous secreting openings distributed in the cuticle, which has been hypothesized to protect the animal from abrasion as it moves through the sediment (Brown 1985; GOrdóñez et al. 2000; Kristensen \& Higgins 1991; Neuhaus 2013). However, this abrasion hypothesis seems unlikely given the high viscosity of water for microinvertebrates living at low Reynolds number, the presence of biofilms coating marine substrates, and the abundance of delicate unarmored meiofauna thriving "unharmed" in interstitial habitats. C. styx has around 30 glandular openings distributed along the trunk and a pair of tubes on segment 5 (Neuhaus \& Kegel 2015). The nature of the secretion of the glands or the function of the tubes in C. styx is uncertain and no conclusions can be drawn until further studies are made.

Mechanical adhesive methods based on interlocking or anchoring and increasing friction against a substrate are universal among metazoans because of their low biological cost (no need of material discharge), simplicity and efficiency (Wolf \& Gorb 2016). These methods work in both aquatic and terrestrial environments with equivalent efficiency despite the different forces involved in each habitat (Ditsche \& Summers 2014), and are, therefore, present in a broad variety of animal groups. Kinorhynchs show a wide variety of cuticular structures (scalids, spines, hairs) that seem to be associated with anchoring to the sediment. However, the genus Cateria and specifically C. styx, appears to have exploited the use of friction to a higher level, showing an extraordinary complex cuticular ornamentation combined with multiple types of cuticular protuberances and even an adhesive dorsal organ. The cuticular ornamentation includes knobby areas, dragon scale-like and palisade-like configurations, whereas the cuticular protuberances include specialized fringe-like hairs. All of these specializations contribute to increase the contact surface of the cuticle with the sediment enhancing the friction and therefore providing a better grip. Similar levels of cuticular complexity to enhance friction are found in other meiofaunal organisms such as mites of the family Nematalycidae (Bolton et al. 2015), the priapulids Meiopriapulus and Tubiluchus (e.g., Schmidt-Rhaesa et al., 2013, 2017; Sørensen et al., 2012c) or gastrotrichs (e.g., Kieneke \& Nikoukar 2017). C. styx also has multiple anchoring structures including lateroventral, middorsal and terminal spines distributed along the trunk, that interlock with the surrounding sediment working in synchrony with the elongation of the trunk and the introvert eversion. The introvert in C. styx shows several modifications such as very flexible and long primary spinoscalids, additional spinoscalids with special ornamentation (rows of plate- like scales), and hairy patches. We infer that all of these modifications contribute to enhance surface contact with the substrate, creating friction and mechanical adhesion to the sediment during locomotion.

\section{Conclusions}

This study has addressed several open questions about the functional morphology of $C$. styx since its discovery nearly 70 years ago, particularly the detailed morphology and putative function of the dorsal organ. Here, we conclude that the dorsal organ is a hydrostatic and most likely retractable structure, formed as a specialization of the intersegmental cuticle of segments 5 and 6 , and which function is inferred to be adhesive. New morphological details on C. styx include: (i) a highly modified introvert showing, on average, half as many scalids as any other kinorhynch genera; (ii) extremely elongated primary spinoscalids that cannot be completely retracted in the trunk; (iii) presence of sixteen hairy patches below the fourth row of spinoscalids; (iv) fifteen trichoscalids varying in length; (v) absence of a distinct neck; (vi) very thin, but extremely ornamented cuticle; (vii) dorsal spines being alternatingly laterally displaced to paradorsal positions; (viii) high variability of number and position of glandular openings in the trunk.

C. styx has a complex array of cuticular structures that we interpret as adaptations to exploit mechanical adhesion in an interstitial habitat through friction and interlocking. Structures that increase friction include: exceptionally long and flexible primary spinoscalids in the introvert, additional spinoscalids with a unique scale-like ornamentation, an extraordinary variety of cuticular relieves in the trunk (e.g., dragon-like scales, palisade-like and fringed areas), and the presence of an eversible dorsal organ that adapts to the sand grain discontinuities providing an extra grip. Structures that interlock with the surrounding sediment include lateroventral, middorsal and terminal spines distributed along the trunk and scalids in the introvert.

The presence of dorsal spines in C. styx being displaced to paradorsal positions is shared with species of Dracoderes, Franciscideres, and a new francisciderid genus, could be a potential synapomorphic trait for these genera.

\section{Acknowledgements}

This research was made possible by a grant from the Calsberg Foundation (Grant No. 2013_01_0035) and from grants to BSL from the Tula Foundation (Centre for Microbial Diversity and Evolution), the National Sciences and Engineering Research Council of Canada (NSERC 2014-05258), and the Canadian Institute for Advanced Research, Program in Integrated Microbial Biodiversity. Our warm thanks also go to Unidade Integrada de Imagens, and Laboratório de Invertebrados from Instituto de Biodiversidade e Sustentabilidade, Federal University of Rio de Janeiro UFRJ (NUPEM/UFRJ - Macaé), Center for Marine Studies, Federal University of Paraná (CEM/UFPR) and Center for Marine Biology (CEBIMar/USP) for offering lab space during our field work. São Paulo Research Foundation (FAPESP Process 2012/08581-0), provided postdoctoral fellowships and grants for MDD.

\section{References}

Altenburger, A., Rho, H.S., Chang, C.Y., Sørensen, M.V., 2015. Zelinkaderes yong sp. nov. From Korea - the first recording of Zelinkaderes (Kinorhyncha: Cyclorhagida) in Asia. Zool. Stud. 54, 25. https://doi.org/10.1186/s40555-014-0103-6. Bauer-Nebelsick, M., 1995. Zelinkaderes klepali sp.n., from shallow water sands of the Red Sea. Ann. Nat. Mus. Wien 97B, 57-74. 
Bauer-Nebelsick, M., 1996. Antygomonas oreas sp.n., a new deep sea kinorhynch from the Pacific Ocean. Ann. Nat. Mus. Wien 98B, 5-22.

Bolton, S.J., Bauchan, G.R., Ochoa, R., Pooley, C., Klompen, H., 2015. The role of the integument with respect to different modes of locomotion in the Nematalycidae (Endeostigmata). Exp. Appl. Acarol. 65, 149-161.

Brown, R., 1985. Developmental and Taxonomic Studies of Sydney Harbour Kinorhyncha. Ph.D.-thesis. Macquarie University, Australia.

Brown, R., Higgins, R.P., 1983. A new species of Kinorhynchus (Homalorhagida, Pycnophyidae) from Australia with a redescription and range extension of other Kinorhyncha from the South Pacific. Zool. Scr. 12, 161-169.

Dal Zotto, M., 2015. Antygomonas caeciliae, a new kinorhynch from the Mediterranean Sea, with report of mitochondrial genetic data for the phylum. Mar. Biol. Res. 11, 689-702. https://doi.org/10.1080/17451000.2015.1007872.

Dal Zotto, M., Di Domenico, M., Garraffoni, A., Sørensen, M.V., 2013. Franciscideres gen. nov. - a new, highly aberrant kinorhynch genus from Brazil, with an analysis of its phylogenetic position. Syst. Biodivers. 11, 303-321. https://doi. org/10.1080/14772000.2013.819045.

Delamare Deboutteville, C., 1957. Sur la présence des Echinodères de la famille des Cateriidae Gerlach dans les eaux souterraines littorales de l Angola. Publicações Culturais da Companhia de Diamantes de Angola 34, 35-37.

Ditsche, P., Summers, A.P., 2014. Aquatic versus terrestrial attachment: water makes a difference. Beilstein J. Nanotechnol. 5, 2424-2439. http://dx.do.org/10.3762 bjnano. 5.252

Gerlach, S.A., 1956. Über einen aberranten Vertreter der Kinorhynchen aus dem Küstengrundwasser. Kiel. Meeresforsch. 12, 120-124.

Giere, O., 2009. Meiobenthology. The Microscopic Fauna in Aquatic Sediments second ed. Springer-Verlag Berlin, Heidelberg, pp. 1-538.

Gorb, S.N., 2008. Biological attachment devices: exploring nature's diversity for biomimetics. Phil. Trans. R. Soc. A 366, 1557-1574. http://dx.do.org/10.1098 rsta.2007.2172.

GaOrdóñez, D., Pardos, F., Benito, J., 2000. Cuticular structures and epidermal glands of Echinoderes cantabricus and E. hispanicus (Kinorhyncha, Cyclorhagida) with special reference to their taxonomic value. J. Morphol. 246, 161-178 https:/ doi.org/10.1002/1097-4687(200012)246:3<161::AID-JMOR1>3.0.CO;2-R.

Herranz, M., Pardos, F., 2013. Fissuroderes sorenseni sp. nov. and Meristoderes boyle sp. nov.: first Atlantic recording of two rare kinorhynch genera, with new identification keys. Zool. Anz. 253, 93-111.

Herranz, M., Thormar, J., Benito, J., Sánchez, N., Pardos, F., 2012. Meristoderes gen. nov., a new kinorhynch genus, with the description of two new species and their implications for echinoderid phylogeny (Kinorhyncha: Cyclorhagida, Echinoderidae). Zool. Anz. 251, 191-179.

Herranz, M., Leander, B., 2016. Redescription of Echinoderes ohtsukai Yamasaki and Kajihara, 2012 and E. kozloffi Higgins, 1977 from the Northwest Pacific coast including the first report of a potential invasive species of kinorhynch. Zool. Anz. 265, 108-126. https://doi.org/10.1016/j.jcz.2016.02.004.

Herranz, M., Sánchez, N., Pardos, F., Higgins, R.P., 2014. New Kinorhyncha from Florida coastal waters. Helgol. Mar. Res. 68, 59-87. https://doi.org/10.1007 s10152-013-0369-9.

Herranz, M., Yangel, E., Leander, B., 2018. Echinoderes hakaiensis sp. nov.: a new mud dragon (Kinorhyncha, Echinoderidae) from the northeastern Pacific Ocean with the redescription of Echinoderes pennaki Higgins, 1960. Mar. Biodivers. 48, 303-325. https://doi.org/10.1007/s12526-017-0726-z.

Higgins, R.P., 1960. A new species of Echinoderes (Kinorhyncha) from Puget sound. Trans. Am. Microsc. Soc. 79, 85-91.

Higgins, R.P., 1964. Three new kinorhynchs from the North Carolina Coast. Bull. Mar: Sci. Gulf Caribb. 14, 479-493.

Higgins, R.P., 1968. Taxonomy and postembryonic development of the Cryptorhagae, a new suborder for the mesopsammic kinorhynch genus Cateria. Trans. Amer. Microsc. Soc. 87, 21-39.

Higgins, R.P., 1986. A new species of Echinoderes (Kinorhyncha: Cyclorhagida) from a coarse-sand California beach. Trans. Am. Microsc. Soc. 105, 266-273.

Higgins, R.P., 1988. Kinorhyncha. In: Higgins, R.P., Thiel, H. (Eds.), Introduction to the Study of Meiofauna. Smithsonian Institution Press, Washington DC, pp. 328-331.

Higgins, R.P., 1990. Zelinkaderidae, a new family of cyclorhagid Kinorhyncha Smithsonian Contrib. Zool. 500,1-26.

Higgins, R.P., Rao, G.C., 1979. Kinorhynchs from the Andaman Islands. Zool. J. Linn. Soc. 67, 75-85

Higgins, R.P., Shirayama, Y., 1990. Dracoderidae, a new family of the cyclorhagid Kinorhyncha from the inland Sea of Japan. Zool. Sci. 7, 939-946.

Ishii, D., Yamasaki, H., Uozumi, R., Hirose, E., 2016. Does the kinorhynch have a hydrophobic body surface? Measurement of the wettability of a meiobenthic metazoan. R. Soc. Open Sci. 3, 160512. https://doi.org/10.1098/rsos.160512.

Jørgensen, A., Kristensen, R.M., 2001. A new tanarctid arthrotardigrade with buoyant bodies. Zool. Anz. 240, 425-439. https://doi.org/10.1078/0044-5231-00051.

Kieneke, A., Nikoukar, H., 2017. Interactive morphological and molecular investigations of Turbanella hyalina Schultze, 1853 (Gastrotricha: Macrodasyida), including a redescription of the species. Zool. Anz. 267, 168-186. https://doi. org/10.1016/j.jcz.2017.03.005

Kristensen, R.M., Higgins, R.P., 1991. Kinorhyncha. In: Harrison, F.W., Ruppert, E.E. (Eds.), Microscopic Anatomy of Invertebrates, vol. 4. Aschelminthes. Wiley-Liss, New York, pp. 377-404.

Lengerer, B., Ladurner, P., 2018. Properties of temporary adhesion systems of marine and freshwater organisms. J. Exp. Biol. 221, jeb182717. https://doi:10.1242/jeb. 182717.
Lou, T.-H., 1934. Sur la presence d'un nouveau kinorhynque a Tchefou: Echinoderes tchefouensis sp. nov. Contrib. Inst. Zool., Nat. Acad. Peiping 1,1-9 (In Chinese with French translation).

McGinty, M., Higgins, R.P., 1968. Ontogenetic variation of taxonomic characters of two marine tardigrades with the description of Batillipes bullacaudatus n. sp. Trans. Am. Microsc. Soc. 87, 252-262.

McLachlan, A., Defeo, O., 2017. The Ecology of Sandy Shores, third ed. Elsevier, London, pp. 1-572.

Nebelsick, M., 1990. Antygomonas incomitata gen. et sp. n. (Cyclorhagida, Kinorhyncha) and its phylogenetic relationships. Zool. Scr. 19, 143-152.

Nebelsick, M., 1993. Introvert, mouth cone, and nervous system of Echinoderes capitatus (Kinorhyncha, Cyclorhagida) and implications for the phylogenetic relationships of Kinorhyncha. Zoomorphology 113, 211-232.

Neuhaus, B., 2013. Kinorhyncha (=Echinodera). In: Schmidt-Rhaesa, A. (Ed.), Handbook of Zoology. Gastrotricha, Cycloneuralia and Gnathifera. Volume 1: Nematomorpha, Priapulida, Kinorhyncha, Loricifera. De Gruyter, Berlin/Boston, pp. 181-348.

Neuhaus, B., Kegel, A., 2015. Redescription of Cateria gerlachi (Kinorhyncha, Cyclorhagida) from Sri Lanka and of C. styx from Brazil, with notes on C. gerlachi from India and C. styx from Chile, and the ground pattern of the genus. Zootaxa 3965, 1-77. https://doi.org/10.11646/zootaxa.3965.1.1.

Neuhaus, B., Pardos, F., Sørensen, M.V., Higgins, R.P., 2013. Redescription, morphology, and biogeography of Centroderes spinosus (Reinhard, 1881) (Kinorhyncha, Cyclorhagida) from Europe. Cah. Biol. Mar. 54, 109-131.

Neuhaus, B., Pardos, F., Sørensen, M.V., Higgins, R.P., 2014. New species of Centroderes (Kinorhyncha: Cyclorhagida) from the Northwest Atlantic ocean, life cycle, and ground pattern of the genus. Zootaxa 3901, 1-69. http://www. mapress.com/zootaxa/2014/s/zt03901 p069.pdf.

Neuhaus, B., Sørensen, M.V., 2013. Populations of Campyloderes sp. (Kinorhyncha, Cyclorhagida): one global species with significant morphological variation? Zool. Anz. 252, 48-75. https://doi.org/10.1016/j.jcz.2012.03.002.

Ostmann, A., Nordhaus, I., Sørensen, M.V., 2012. First recording of kinorhynchs from Java, with the description of a new brackish water species from a mangrovefringed lagoon. Mar. Biodivers. 42, 79-91. https://doi.org/10.1007/s12526-0110094-z.

Rao, G.C., Ganapati, P.N., 1966. Occurrence of an aberrant kinorhynch Cateria styx Gerlach, in Waltair beach sands. Curr. Sci. 35, 212-213.

Reinhard, W., 1881. Über Echinoderes and Desmoscolex der Umgegend von Odessa. Zool. Anz. 4, 588-592.

Sánchez, N., Herranz, M., Benito, J., Pardos, F., 2014. Pycnophyes almansae sp. nov. and Pycnophyes lageria sp. nov., two new homalorhagid kinorhynchs (Kinorhyncha: Homalorhagida) from the Iberian Peninsula, with special focus on the introvert features. Mar. Biol. Res. 10, 17-36. https://doi.org/10.1080/17451000. 2013.793804.

Sánchez, N., Rho, H.S., Min, W.-G., Kim, D., Sørensen, M.V., 2013. Four new species of Pycnophyes (Kinorhyncha: Homalorhagida) from Korea and the East China sea. Sci. Mar. 77, 353-380. https://doi.org/10.3989/scimar.03769.15A.

Schmidt-Rhaesa, A., Panpeng, S., Yamasaki, Y., 2017. Two new species of Tubiluchus (Priapulida) from Japan. Zool. Anz. 267, 155-167. https://doi.org/10.1016/j.jcz. 2017.03.004.

Schmidt-Rhaesa, A., Rothe, B.H., Martínez, A.G., 2013. Tubiluchus lemburgi, a new species of meiobenthic Priapulida. Zool. Anz. 253, 158-163. https://doi.org/10. 1016/j.jcz.2013.08.004.

Sørensen, M.V., 2007. A new species of Antygomonas (Kinorhyncha: Cyclorhagida) from the Atlantic coast of Florida, USA. Cah. Biol. Mar. 48, 155-168.

Sørensen, M.V., 2008. A new kinorhynch genus from the Antarctic deep-sea and a new species of Cephalorhyncha from Hawaii (Kinorhyncha: Cyclorhagida: Echinoderidae). Org. Divers. Evol. 8, 233-246. https://doi.org/10.1016/j.ode. 2007.11.003.

Sørensen, M.V., 2014. First account of echinoderid kinorhynchs from Brazil, with the description of three new species. Mar. Biodivers. 44, 251-274.

Sørensen, M.V., Dal Zotto, M., Rho, H.S., Herranz, M., Sánchez, N., Pardos, F., Yamasaki, H., 2015. Phylogeny of Kinorhyncha based on morphology and two molecular loci. PLoS One 10 (7), e0133440.

Sørensen, M.V., Grzelak, K., 2018. New mud dragons from Svalbard: three new species of Cristaphyes and the first Arctic species of Pycnophyes (Kinorhyncha: Allomalorhagida: Pycnophyidae). PeerJ 6, e5653. https://doi.org/10.7717/peerj. 5653.

Sørensen, M.V., Heiner, I., Hansen, J.G., 2009. A comparative morphological study of the kinorhynch genera Antygomonas and Semnoderes (Kinorhyncha: Cyclorhagida). Helgol. Mar. Res. 63, 129-147.

Sørensen, M.V., Heiner, I., Ziemer, O., 2005. A new species of Echinoderes from Florida (Kinorhyncha: Cyclorhagida). Proc. Biol. Soc. Wash. 118, 499-508.

Sørensen, M.V., Heiner, I., Ziemer, O., Neuhaus, B., 2007. Tubulideres seminoli gen. et sp. nov. and Zelinkaderes brightae sp. nov. (Kinorhyncha, Cyclorhagida) from Florida. Helgol. Mar. Res, 61, 247-265.

Sørensen, M.V., Herranz, M., Landers, S.C., 2016. A new species of Echinoderes (Kinorhyncha: Cyclorhagida) from the Gulf of Mexico, with a redescription Echinoderes bookhouti Higgins, 1964. Zool. Anz. 265, 48-68. https://doi.org/10. 1016/j.jcz.2016.04.004.

Sørensen, M.V., Herranz, M., Rho, H.S., Min, W., Yamasaki, H., Sánchez, N., Pardos, F., 2012a. On the genus Dracoderes Higgins \& Shirayama, 1990 (Kinorhyncha: Cyclorhagida) with a redescription of its type species, D. abei, and a description of a new species from Spain. Mar. Biol. Res. 8, 210-232. 
Sørensen, M.V., Landers, S.C., 2014. Two new species of Echinoderes (Kinorhyncha: Cyclorhagida) from the Gulf of Mexico. Front. Mar. Sci. 1, 1-18 article 8.

Sørensen, M.V., Landers, S.C., 2017. Description of a new species, Paracentrophyes sanchezae n. sp. (Kinorhyncha: Allomalorhagida) from the Gulf of Mexico, with differential notes on one additional, yet undescribed species of the genus. Zootaxa 4242, 61-76. https://doi.org/10.11646/zootaxa.4242.1.3.

Sørensen, M.V., Landers, S.C., 2018. New species of Semnoderidae (Kinorhyncha: Cyclorhagida: Kentrorhagata) from the Gulf of Mexico. Mar. Biodivers. 48, 327-355. https://doi.org/10.1007/s12526-017-0728-x.

Sørensen, M.V., Pardos, F., 2008. Kinorhynch systematics and biology - an introduction to the study of kinorhynchs, inclusive identification keys to the genera. Meiofauna Mar. 16, 21-73.

Sørensen, M.V., Pardos, F., Herranz, M., Rho, H.S., 2010a. New data on the genus Paracentrophyes (Homalorhagida, Kinorhyncha), with the description of a new species from the west Pacific. Open Zool. J. 3, 42-59.

Sørensen, M.V., Rho, H.S., 2009. Triodontoderes anulap gen. et sp. nov. - a new cyclorhagid kinorhynch genus and species from Micronesia. J. Mar. Biol. Assoc. UK 89, 1269-1279. https://doi.org/10.1017/S0025315409000526.

Sørensen, M.V., Rho, H.S., Kim, D., 2010b. A new species of Condyloderes (Cyclorhagida, Kinorhyncha) from Korea. Zool. Sci. 27, 234-242.

Sørensen, M.V., Rho, H.S., Min, W.G., Kim, D., Chang, C.Y., 2012b. An exploration of Echinoderes (Kinorhyncha: Cyclorhagida) in Korean and neighboring waters, with the description of four new species and a redescription of E. tchefouensis Lou, 1934. Zootaxa 3368, 161-196.

Sørensen, M.V., Rho, H.S., Min, W.G., Kim, D., 2012c. A new recording of the rare priapulid Meiopriapulus fijiensis, with comparative notes on juvenile and adult morphology. Zool. Anz. 251, 364-371. https://doi.org/10.1016/j.jcz.2011.10.001.

Sørensen, M.V., Rho, H.S., Min, W.G., Kim, D., Chang, C.Y., 2013. Occurrence of the newly described kinorhynch genus Meristoderes (Cyclorhagida: Echinoderidae) in Korea, with the description of four new species. Helgol. Mar. Res. 67, 291-319.

Sørensen, M.V., Rohal, M., Thistle, D., 2018. Deep-sea Echinoderidae (Kinorhyncha: Cyclorhagida) from the Northwest Pacific. Eur. J. Taxon. 456, 1-75. https://doi. org/10.5852/ejt.2018.456.

Sørensen, M.V., Thormar, J., 2010. Wollunquaderes majkenae gen. et sp. nov. - a new cyclorhagid kinorhynch genus and species from the Coral Sea, Australia. Mar. Biodivers. 40, 261-275. https://doi.org/10.1007/s12526-010-0048-x.
Thomsen, V.G., Rho, H.S., Kim, D., Sørensen, M.V., 2013. A new species of Dracoderes (Kinorhyncha: Dracoderidae) from Korea provides further support for a dracoderid-homalorhagid relationship. Zootaxa 3682, 133-142.

Wolf, J.O., Gorb, S.N., 2016. Mechanical attachment devices. In: Gorb, S.N. Albrecht, C. (Eds.), Biologically-Inspired Systems. Volume 7: Attachment Structures and Adhesive Secretions in Arachnids. Springer, Berlin, pp. 25-48.

Yamasaki, H., 2016. Ryuguderes iejimaensis, a new genus and species of Campyloderidae (Xenosomata: Cyclorhagida: Kinorhyncha) from a submarine cave in the Ryukyu Islands, Japan. Zool. Anz. 265, 69-79. https://doi.org/10.1016/j.jcz. 2016.02.003.

Yamasaki, H., 2019. Gracilideres mawatarii, a new genus and species of Franciscideridae (Allomalorhagida: Kinorhyncha) from Japan with morphological comparison of head characters, and special attention to thin-cuticle body of Kinorhyncha in relation to adaptation to interstitial environment. Zool. Anz. 282, 176-188. https://doi.org/10.1016/j.jcz.2019.05.010.

Yamasaki, H., Durucan, F, 2018. Echinoderes antalyaensis sp. nov. (Cyclorhagida: Kinorhyncha) from Antalya, Turkey, Levantine sea, Eastern mediterranean sea. Species Divers. 23, 193-207. https://doi.org/10.12782/specdiv.23.193.

Yamasaki, H., Fujimoto, S., 2014. Two new species in the Echinoderes coulli group (Echinoderidae, Cyclorhagida, Kinorhyncha) from the Ryukyu Islands, Japan. ZooKeys 382, 27-52. https://doi.org/10.3897/zookeys.382.6761.

Yamasaki, H., Kajihara, H., 2012. A new brackish-water species of Echinoderes (Kinorhyncha: Cyclorhagida) from the Seto inland sea. Japan. Species Div. 17, 109-118. https://doi.org/10.12782/sd.17.1.109.

Yamasaki, H., Grzelak, K., Sørensen, M.V., Neuhaus, B., George, K.H., 2018. Echinoderes pterus sp. n. showing a geographically and bathymetrically wide distribution pattern on seamounts and on the deep-sea floor in the Arctic Ocean, Atlantic Ocean, and the Mediterranean Sea (Kinorhyncha, Cyclorhagida). ZooKeys 771, 15-40. https://doi.org/10.3897/zookeys.771.25534.

Yildiz, N.O., Sørensen, M.V., Karaytuğ, S., 2016. A new species of Cephalorhyncha Adrianov, 1999 (Kinorhyncha: Cyclorhagida) from the Aegean coast of Turkey. Helgol. Mar. Res. 70, 24. https://doi.org/10.1186/s10152-016-0476-5.

Zelinka, C., 1913. Der Echinoderen der Deutschen Südpolar-Expedition, 1901-1903. Band 14. Reimer, Berlin.

Zelinka, C., 1928. Monographie der Echinodera. Verlag Wilhelm Engelmann, Leipzig. 